\title{
Sectograph による顆頭位の研究
}

第 3 報 成人および小児における T.M.J. 付近の状態と顆頭の動きについて 高橋 健二 早坂 正博 田中 義博 近江谷尚紀 酒井 靖彦 田島 篤治

\section{A Study of Condylar Position with Sectograph}

Part 3. Morphological Studies of Temporomandibular Joint on Adult and Child

Kenji Takashi, Masahiro Hayasaka, Yoshihiro Tanaka, Naoki Omiya, Yasuhiko Sakai and Tokuji Tajima

\section{I. 緒 論}

顎関節ならびに下頞運動に関する研究は，補緅的分野 における診断上の重要な情報ならびに咬合面の構成を主 体とする治療術式の確立という立場からすこぶる重要な 要素として注目されてきた1). 特に下額運動に関するも のは Monro u.Ferrein (1737, 1744 年) 以来多数の報告 がみられ, 解剖学的方法 ${ }^{2 \sim 4}$, チェックバイト法5 7), 描 記法 ${ }^{8 \sim 10)}$, 電球またはストロボ写真法 ${ }^{11 ~ 13), ~ X ~} \mathrm{X}$ 線写真

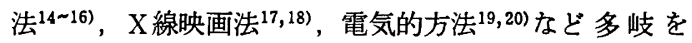
きわめており, 運動の実体も解明されようとしている.

しかし, 補綴学的観点から下䫟運動およぴ T.M.J. に 関する研究が進められてきたため, 小児におけるそれら の研究が等閑視されたものと思われる. したがってこれ らの分野ではわずかに乾燥頭蓋を用いた T.M.J. 付近の 形態に関する研究がみられるのみで, 規格断層X線写真 による研究は Alan High ${ }^{21)}$ (1978年) のみであり,さ らに下顎運動に関するものはきわめて数少ないのが現状 である。

すでにわれわれは Cephalometric laminagraph「Sec-

東北歯科大学歯科補緅学第 2 請座 (主任: 田島篤治教授)

Tohoku Dental University, Department of Removable Prosthodontics (Chief : Prof. Tokuji Tajima) 炤和 58 年 4 月 15 日受付 tograph」を利用し，第 1 報および第 2 報において，成 人における T.M.J. 付近の形態ならびに下顎運動につい て報告した ${ }^{22,23)}$ ，そこで今回は，前報よりえられた情報 をもととし，小児における T.M.J. 付近の形態と centric position および eccentric position における顆頭の 挙動と同時に, 関節窩内の空間変化について む image analyzer を使用して検索を行った.

\section{II. 研究方法}

1. 撮影およびトレーシング法

頭部規格断層X線撮影装㯰として, 米国 Quint 社製 Sectograph を利用し, 顆頭中央をとおりフィルム方向 へ 15 度回転させた断面を対象として撮影を行った. 断 層撮影面の決定にあたっては, 頭部規格X線写真法によ り撮影した前頭面像によって顆頭閒距離の測定を行うと 同時に，解剖的計測基準に準じた顆頭中央部指定法すな わち煩部表面計測による煩骨弓幅の $1 / 2$ より $18 \mathrm{~mm}$ を 減じた值を参考とした. 撮影条件は, 焦点 $1.0 \times 1.0$ $\mathrm{mm}^{2}$, 焦点フィルム間距離 $1,650 \mathrm{~mm}$, フィルム断層面間 距離は成人で平均 $80 \mathrm{~mm}$, 小児では平均 $85 \mathrm{~mm}$, 管電 圧 $76 \mathrm{kVp}$, 管電流 $100 \mathrm{~mA}$ ，フィルムはさくら $\mathrm{AL}$ タ イプ, 増感紙は東芝 $\mathrm{RM}$, 有効管球移動角度は 15 度で ある. 頭部の固定にあたっては撮影側フィルム面に対面 するように被験者を撮影用椅子に通常の座位の姿勢で固 


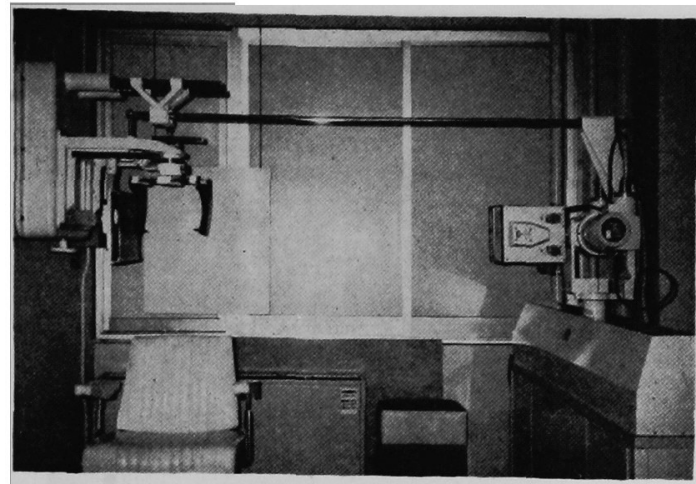

図 1 頭部規格断層X線撮影装置 Sectograph

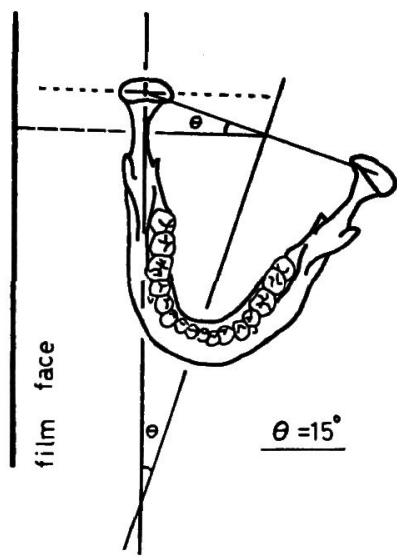

図 2 撮影断層面

定し, 両側外耳道に ear rod を挿入した（表 1 , 図 1 , 2,3).

なお前後的あおりの固定は眼点に接触する固定装置を 用いた. また, 各条件に拉ける Sectogram についてト レーシングを行い計測原図とした（図4).

\section{2. 被験者, 顎位および測定対象}

1) 被験者および被験枵

成人群は平均年齡 23 歳の男女 10 名, 小児群としては 平均年齢 10 歳の男女 10 名を被験者とした.

なお，成人群は第 3 大臼歯以外の久如を認めす，また 成人群执よび小児群ともに咬合状態および歯周組織が正 常であり，歯冠修復がある場合であっても咬合の変化を きたす範囲にわたらないものであり，かつ臨床的な診查 において咀嚼筇群あるいは顎関節の異常は認められない ものである。
表 1 各被験者の顆頭頂間距離

\begin{tabular}{c|c|c|c}
\hline \hline & \multicolumn{2}{c}{ adult } & \multicolumn{2}{c}{ child } \\
\hline A & 98 & a & 82 \\
B & 96 & b & 92 \\
C & 98 & c & 82 \\
D & 100 & d & 88 \\
E & 102 & e & 88 \\
F & 106 & f & 98 \\
G & 100 & g & 100 \\
H & 100 & h & 88 \\
I & 104 & i & 94 \\
J & 90 & j & 84 \\
\hline M & 99.4 & M & 89.6 \\
SD & 4.4 & SD & 6.3 \\
max. & 106 & max. & 100 \\
min. & 90 & min. & 82 \\
\hline \multicolumn{2}{|r}{}
\end{tabular}

被験側は各被験者の左右，すなわち成人群および小児 群各々 20 側である.

2) 撮影顎位

被験者の䫟関節の断層撮影時の咬合条件は, i. $<\mathrm{p}:$ 咬 頭嵌合位, および n.w.s : 前歯部で $5 \mathrm{~mm}$ 移動時の非作 業側である(表 2).

3) 測定対象

(1) 関節窩の形態

a）関節窩前方部の大きさ

下䫟運動時における不動側要素として重要と思われる 関節窝前方部分の形態を, F-H 平面を水平基準として図 に示すように関節䆟最高点と最低点から，前後的な距離 fi と上下的な距離 fd の測定を行った（図 5).

b）関節窩前壁の傾斜度

関節窩前壁における最高点最低点間の曲線部を 4 分割 し，最高点および最低点よりそれぞれ $1 / 4$ の 2 点を結ん だ直線をもって曲線部中央の平均的傾斜度とみなし, F-H 平面に対する $\theta$ を測定した (図 6).

(2) 関節窩壁と顆頭との最接近距離

咬頭嵌合位および非作業側における関節窝内の顆頭位 を調査した.

調査にあたっては関節窩前壁あるいは後壁と顆頭との 最短距離の測定を行った. すなわち $\mathrm{F}-\mathrm{H}$ 平面に対し 45 度に交わる 2 本の基淮線を設定し,これに平行な最短距 離をもって関節窩壁顆頭閒距離とした（図7).

(a) $\mathrm{Pd}$ : 関節窩前壁と顆頭との最も接近した距離.

(b) Rd : 関節窩後壁と顆頭との最も接近した距離. 

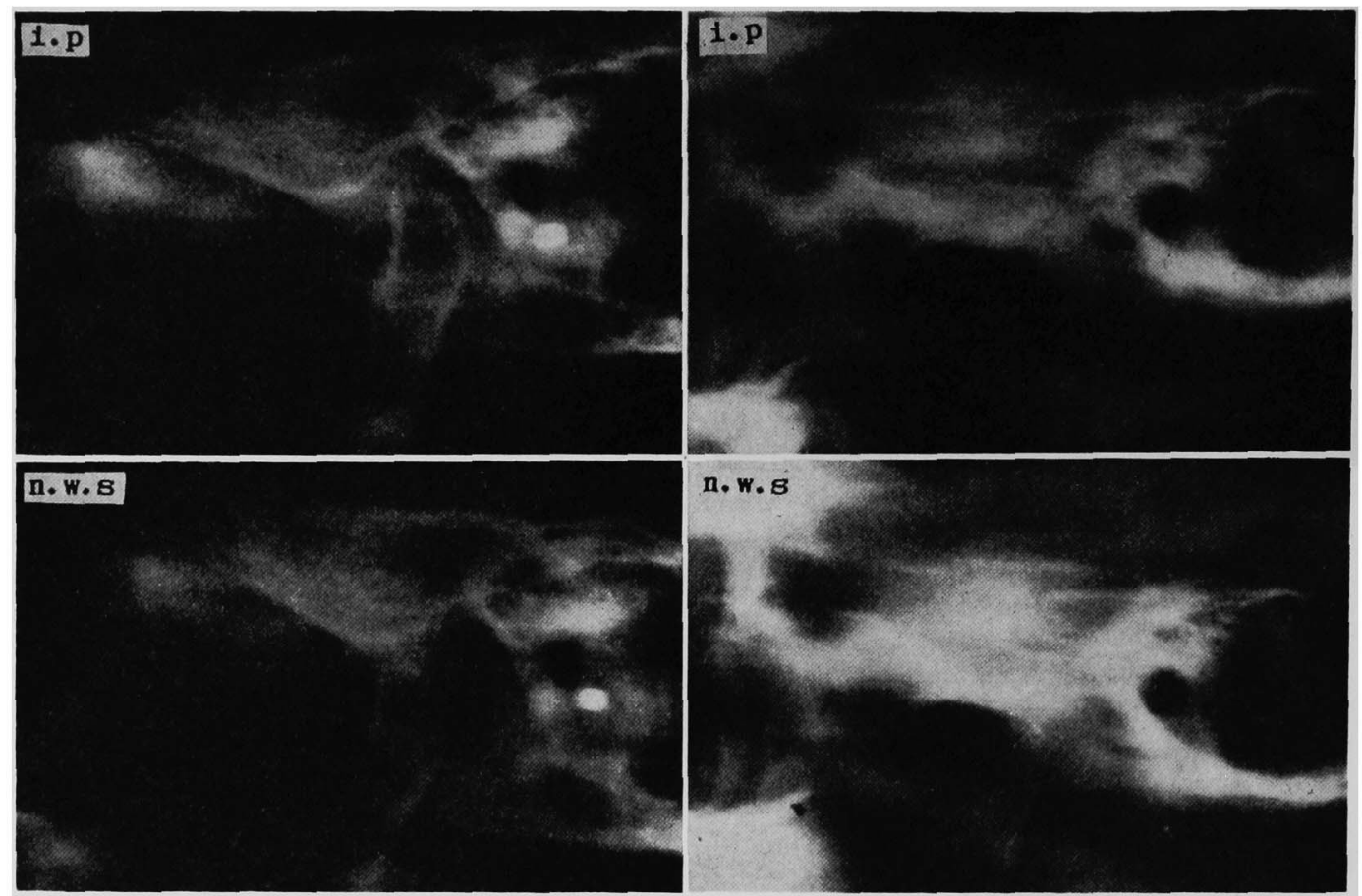

図 3 Sectogram

左上: 成人の咬頭炭合位 右上：小児の咬頭嵌合位 左下 : 成人の非作業側 右下 : 小児の非作業側

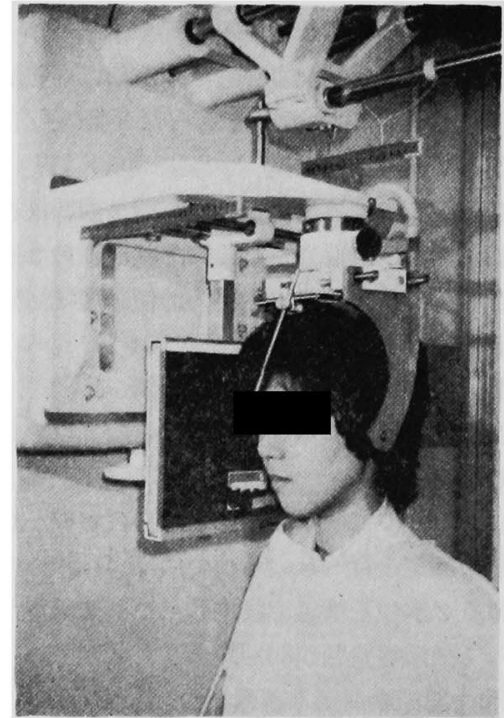

图 4 頭部固定

\begin{tabular}{|c|c|}
\hline \multicolumn{2}{|l|}{ adult } \\
\hline $\begin{array}{l}\text { i.p } \\
\text { n.w.s }\end{array}$ & $\begin{array}{l}\text { intercuspidated position } \\
\text { non-working side }\end{array}$ \\
\hline \multicolumn{2}{|l|}{ child } \\
\hline $\begin{array}{l}\text { i. p } \\
\text { n. w. s }\end{array}$ & $\begin{array}{l}\text { intercuspidated position } \\
\text { non-working side }\end{array}$ \\
\hline
\end{tabular}

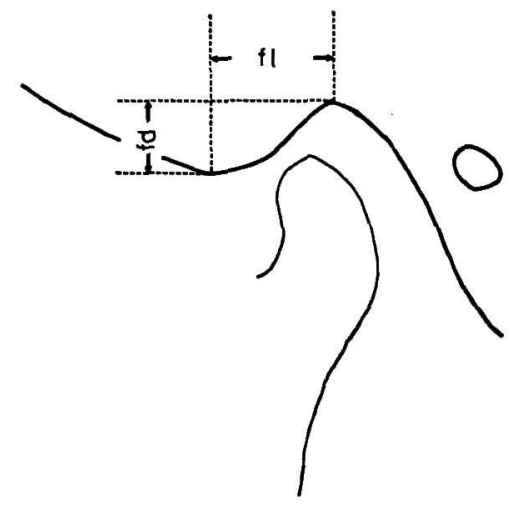

図 5 関節窝前方部測定部位 


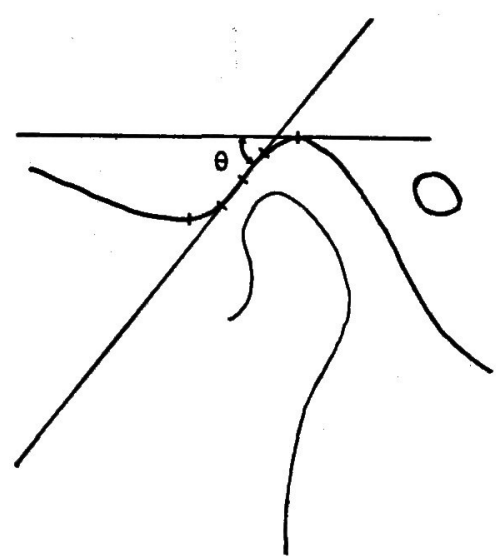

図 6 関節窝前壁傾斜度測定法

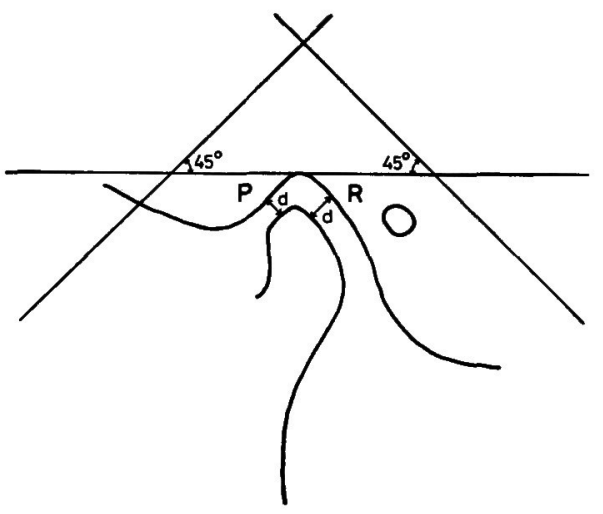

図 7 関節䔰前壁および後壁と顆頭との最接近距離

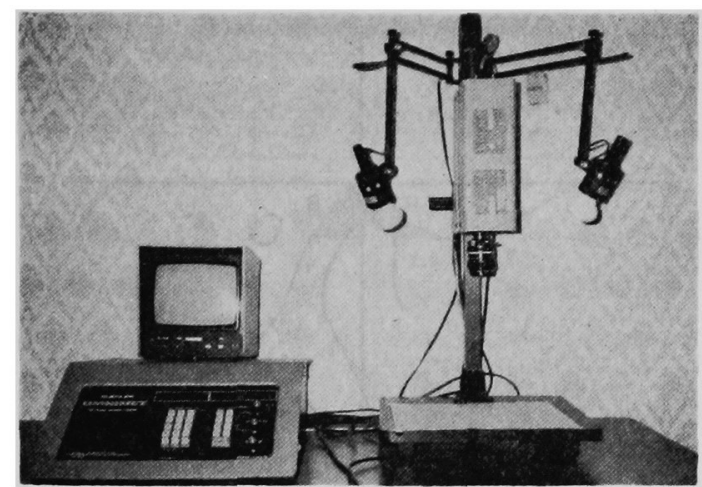

図 8 image analyzer

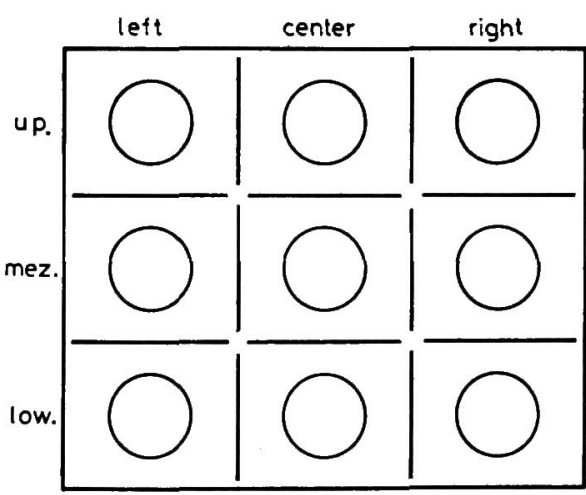

図 9 image analyzer のテレビジョン画面におけ る測定誤差調査部位

表 3 image analyzer 測定誤差調查結果

measuring positions

\begin{tabular}{c|c|c|c|c|c|c|c|c|c}
\hline & up. left & mez. left & low. left & up.center & mez. center & low. center & up. right & mez. right & low. right \\
\hline 1 & 182182 & 181678 & 181284 & 181927 & 181306 & 180635 & 183552 & 182705 & 181834 \\
2 & 182198 & 181674 & 181307 & 181911 & 181320 & 180626 & 183508 & 182688 & 181782 \\
3 & 182247 & 181652 & 181294 & 181907 & 181313 & 180616 & 183486 & 182671 & 181817 \\
4 & 182176 & 181672 & 181286 & 181919 & 181343 & 180614 & 183468 & 182664 & 181776 \\
5 & 182247 & 181671 & 181321 & 181911 & 181335 & 180635 & 183476 & 182661 & 181788 \\
6 & 182196 & 181666 & 181313 & 181930 & 181329 & 180639 & 183516 & 182649 & 181792 \\
7 & 182188 & 181687 & 181305 & 181912 & 181329 & 180611 & 183524 & 182652 & 181758 \\
8 & 182206 & 181654 & 181312 & 181938 & 181330 & 180644 & 183519 & 182655 & 181781 \\
9 & 182169 & 181659 & 181309 & 181931 & 181345 & 180608 & 183480 & 182663 & 181806 \\
10 & 182168 & 181616 & 181274 & 181919 & 181295 & 180631 & 183492 & 182651 & 181820 \\
\hline M & 182198 & 181663 & 181301 & 181921 & 181325 & 180626 & 183502 & 182666 & 181795 \\
\hline SD & 28.7131 & 19.6356 & 15.0555 & 10.4350 & 15.9513 & 12.7366 & 26.1406 & 17.8885 & 23.2857 \\
\hline max. & 182247 & 181687 & 181321 & 181938 & 181345 & 180644 & 183552 & 182705 & 181834 \\
\hline min. & 182168 & 181616 & 181274 & 181907 & 181295 & 180608 & 183468 & 182649 & 181758 \\
\hline
\end{tabular}




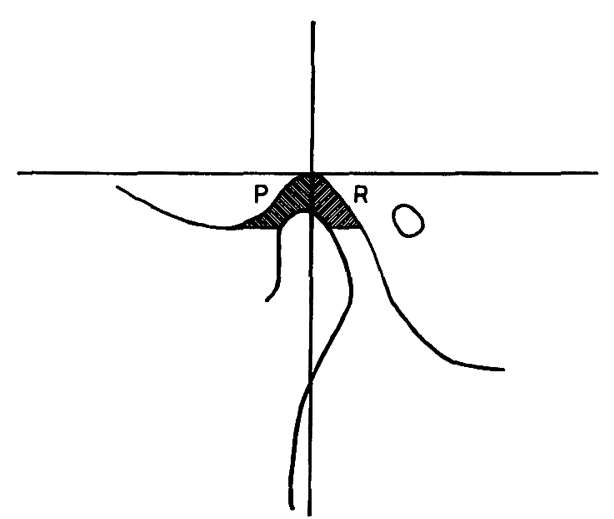

图 10 関節窝顆頭間空陌の断面皘測定域

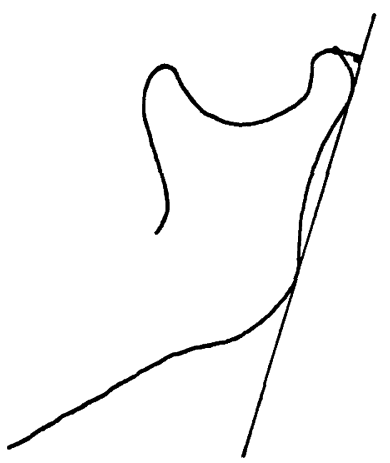

図 11 顆頭頂決定法

測定にあたっては，米国 Buehler 社の image analyzer を使用し最接近部位を捜査すると同時に，その距離 を測定した (図 8).

この分析装置はテレビジョンの画素すなわちメジャリ ング・ポイントを利用し，比例的に距離㧍よび面積の測 定を行うものである.

測定に先立ち, 画面を上下 3 段 (up., mez., low.) に 分け，また左右 3 区分 (left, center, right) し, 計 9 域 における測定誤差を調査した. 測定誤差は画面に対する 被写体の大きさの比率にも影響を受けるが，われわれの 測定における被写体比率にあっては, 面積測定の場合, 最大值一最小值差は $0.028 \%$ であり, 被写体の位置ずれ を考虑に入れても最大 $1.62 \%$ 以内の測定が可能である (表 3, 図9).

(3) 関節窩顆頭間空隙の断面積

関節窝内の顆頭位の表現にあたって，関節窝顆頭閒空 隙の断面積測定をも行った. 最接近距離の測定と同様, image analyzer を使用して咬頭嵌合位および非作業側

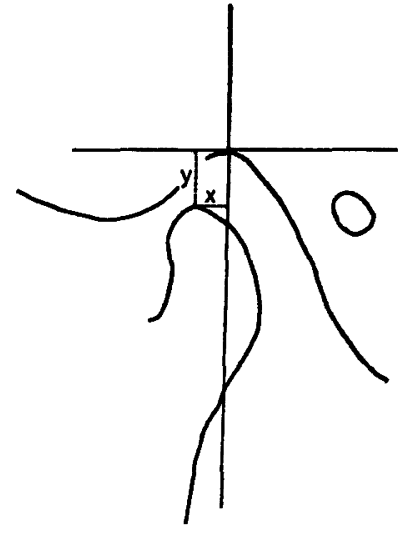

図 12 関節窝最高点を基淮とした顆頭頂の測定

における関節曧顆頭間空隙の断面積を測定した.

関節窝顆頭閒空隙 : (a) whole (area), および関節窝最 高点をとおり F-H 平面に垂直な直線によって関節窩顆 頭間空隙を 2 分し前方域 : (b) area P および後方城 : (c) area $\mathrm{R}$ とし各々測定を行った（図 10).

(4) 各頡位における顆頭頂の位置

下顎骨枝後縁豊隆部を結んだ線を基準として最も高い 点をもって顆頭頂とみなし, 関節窝最高点を基準として 前後および上下的な位置すなわち $\mathrm{x}$ と $\mathrm{y}$ とついて測定 を行った（図 11，12）.

(5) 顆頭頂の移動

つぎにあげる各被験者群における顆頭頂の移動につい て調查を行った.

(a) 成人群における咬頭郄合位から非作業側にいたる 変化.

（b）小児群における咬頭嵌合位から非作業側にいたる 変化.

\section{III. 研究結果}

研究方法において述べた各条件下における成人群およ び小児群の顎関節，および顆頭頂ならびに下頡骨の形態 的調查結果は下記のとおりである.

\section{1. 関節窝の形態}

1）関節窝前方部の大きさ

関節䆟前方部分の形態を $\mathrm{F}-\mathrm{H}$ 平面を水平基準とし関 節窝最高点と最低点の位置より, 前後的な距離 $\mathrm{fl}$ は, 成人群で最大 $14.50 \mathrm{~mm}$, 最小 $6.75 \mathrm{~mm}$, 平均 10.610 $\mathrm{mm}$, 標準偏差 $1.625 \mathrm{~mm}$ であり，小児群では最大 15.10 
表 4 関節窝前方部の大きさ測定結果

\begin{tabular}{c|c|c|c|c|c}
\hline \multicolumn{2}{c}{} & \multicolumn{3}{c}{ adult } & \multicolumn{2}{c}{ child } \\
\hline & fl & fd & & fl & fd \\
\hline $\mathrm{Ar}$ & 9.00 & 7.00 & $\mathrm{ar}$ & 11.80 & 6.50 \\
$\mathrm{Al}$ & 9.60 & 7.50 & $\mathrm{al}$ & 11.90 & 6.70 \\
$\mathrm{Br}$ & 9.50 & 6.20 & $\mathrm{br}$ & 11.60 & 7.70 \\
$\mathrm{Bl}$ & 10.50 & 6.20 & $\mathrm{bl}$ & 10.80 & 6.60 \\
$\mathrm{Cr}$ & 11.10 & 6.25 & $\mathrm{cr}$ & 10.60 & 6.20 \\
$\mathrm{Cl}$ & 10.80 & 8.70 & $\mathrm{cl}$ & 9.20 & 5.50 \\
$\mathrm{Dr}$ & 9.80 & 7.90 & $\mathrm{dr}$ & 9.30 & 8.70 \\
$\mathrm{Dl}$ & 11.30 & 8.00 & $\mathrm{dl}$ & 11.30 & 8.60 \\
$\mathrm{Er}$ & 11.30 & 9.50 & $\mathrm{er}$ & 9.20 & 6.20 \\
$\mathrm{El}$ & 14.50 & 8.35 & $\mathrm{el}$ & 15.10 & 5.70 \\
$\mathrm{Fr}$ & 6.75 & 6.45 & $\mathrm{fr}$ & 9.30 & 9.40 \\
$\mathrm{Fl}$ & 11.40 & 8.15 & $\mathrm{fl}$ & 10.00 & 9.60 \\
$\mathrm{Gr}$ & 12.50 & 7.90 & $\mathrm{gr}$ & 11.70 & 6.50 \\
$\mathrm{Gl}$ & 11.70 & 6.45 & $\mathrm{gl}$ & 7.20 & 6.80 \\
$\mathrm{Hr}$ & 11.00 & 8.75 & $\mathrm{hr}$ & 9.70 & 4.35 \\
$\mathrm{Hl}$ & 10.80 & 7.40 & $\mathrm{hl}$ & 8.90 & 6.10 \\
$\mathrm{Ir}$ & 8.40 & 8.40 & $\mathrm{ir}$ & 8.90 & 5.50 \\
$\mathrm{Il}$ & 9.80 & 8.15 & $\mathrm{il}$ & 11.40 & 4.80 \\
$\mathrm{Jr}$ & 12.10 & 6.45 & $\mathrm{jr}$ & 13.60 & 6.35 \\
$\mathrm{Jl}$ & 10.35 & 3.60 & $\mathrm{jl}$ & 14.00 & 12.00 \\
\hline $\mathrm{M}$ & 10.610 & 7.365 & $\mathrm{M}$ & 10.775 & 6.990 \\
$\mathrm{SD}$ & 1.625 & 1.324 & $\mathrm{SD}$ & 1.954 & 1.847 \\
$\mathrm{max}$. & 14.50 & 9.50 & $\mathrm{max}$ & 15.10 & 12.00 \\
$\mathrm{~min}$ & 6.75 & 3.60 & $\mathrm{~min}$. & 7.20 & 4.35 \\
\hline & & & & & \\
& & & & & \\
\hline
\end{tabular}

左 : 成人群, 右 : 小児群

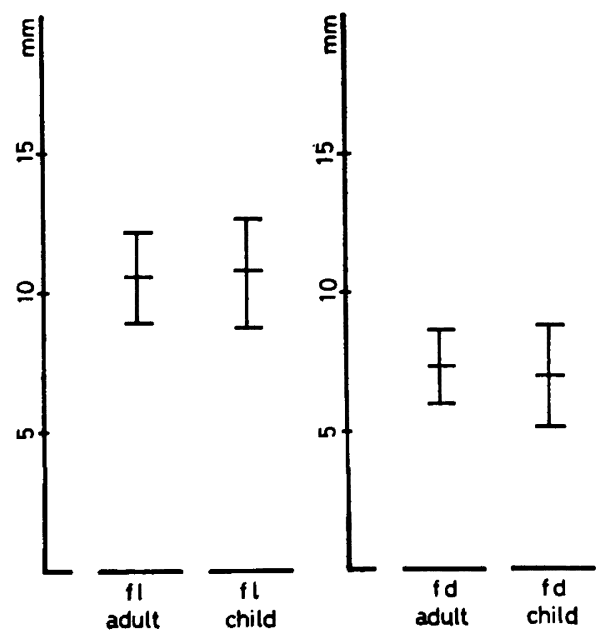

因 13 関節窝前方部の大きさ
表 5 関節窝前壁傾斜度測定結果

\begin{tabular}{|c|c|c|c|}
\hline \multicolumn{2}{|r|}{ adult } & \multicolumn{2}{|r|}{ child } \\
\hline & $\theta$ & & $\theta$ \\
\hline $\mathrm{Ar}$ & 60 & ar & 44 \\
\hline $\mathrm{Al}$ & 62 & al & 39 \\
\hline $\mathrm{Br}$ & 41 & br & 53 \\
\hline $\mathrm{Bl}$ & 45 & bl & 51 \\
\hline $\mathrm{Cr}$ & 48 & $\mathbf{c r}$ & 44 \\
\hline $\mathrm{Cl}$ & 60 & cl & 53 \\
\hline $\mathrm{Dr}$ & 42 & $\mathrm{~d} \mathbf{r}$ & 59 \\
\hline $\mathrm{Dl}$ & 41 & $\mathrm{dl}$ & 51 \\
\hline $\mathrm{Er}$ & 63 & er & 45 \\
\hline El & 43 & el & 29 \\
\hline $\mathrm{Fr}$ & 63 & $\mathrm{fr}$ & 68 \\
\hline $\mathrm{Fl}$ & 51 & fl & 78 \\
\hline $\mathrm{Gr}$ & 44 & $\mathbf{g r}$ & 37 \\
\hline Gl & 45 & $\mathrm{gl}$ & 69 \\
\hline $\mathrm{Hr}$ & 57 & $\mathrm{hr}$ & 29 \\
\hline $\mathrm{Hl}$ & 55 & hl & 54 \\
\hline Ir & 81 & ir & 42 \\
\hline Il & 67 & il & 27 \\
\hline $\mathrm{Jr}$ & 43 & $\mathrm{jr}$ & 37 \\
\hline $\mathrm{Jl}$ & 25 & jl & 37 \\
\hline M & 51.8 & $\mathbf{M}$ & 47.3 \\
\hline $\mathrm{SD}$ & 12.5 & SD & 13.8 \\
\hline $\max$ & 81 & $\max$ & 78 \\
\hline $\min$. & 25 & $\min$ & 27 \\
\hline
\end{tabular}

$\mathrm{mm}$, 最小 $7.20 \mathrm{~mm}$, 平均 $10.775 \mathrm{~mm}$, 標準偏差 1.954 $\mathrm{mm}$ であった。 また, 上下的な距離 $\mathrm{fd}$ は, 成人群で最 大 $9.50 \mathrm{~mm}$, 最小 $3.60 \mathrm{~mm}$, 平均 $7.365 \mathrm{~mm}$, 標準偏差 $1.324 \mathrm{~mm}$ であり，小児群では最大 $12.00 \mathrm{~mm}$, 最小 $4.35 \mathrm{~mm}$, 平均 $6.990 \mathrm{~mm}$, 標準偏差 $1.847 \mathrm{~mm}$ であった (表 4, 図 13).

2）関節窝前壁の傾斜度

関節窝前壁の最高点および最低点よりそれぞれ $1 / 4$ 中 央寄りの 2 点を結んだ直線を曲線部中央の平均的傾斜度 とみなした場合の F-H 平面に対する $\theta$ は，成人群で最 高 81 度, 最低 25 度, 平均 51.8 度, 標準偏差 12.5 度で あり，小児群では最高 78 度, 最低 27 度, 平均 47.3 度, 標準偏差 13.8 度であった（表 5, 図 14, 15).

\section{2. 関節窩壁と顆頭との最接近距離}

咬頭嵌合位および非作業側における関節窩内の顆頭位 の表現として, Pd (関節窝前壁と顆頭との最も接近した 距離）と Rd（関節窩後壁と顆頭との最も接近した距離） 

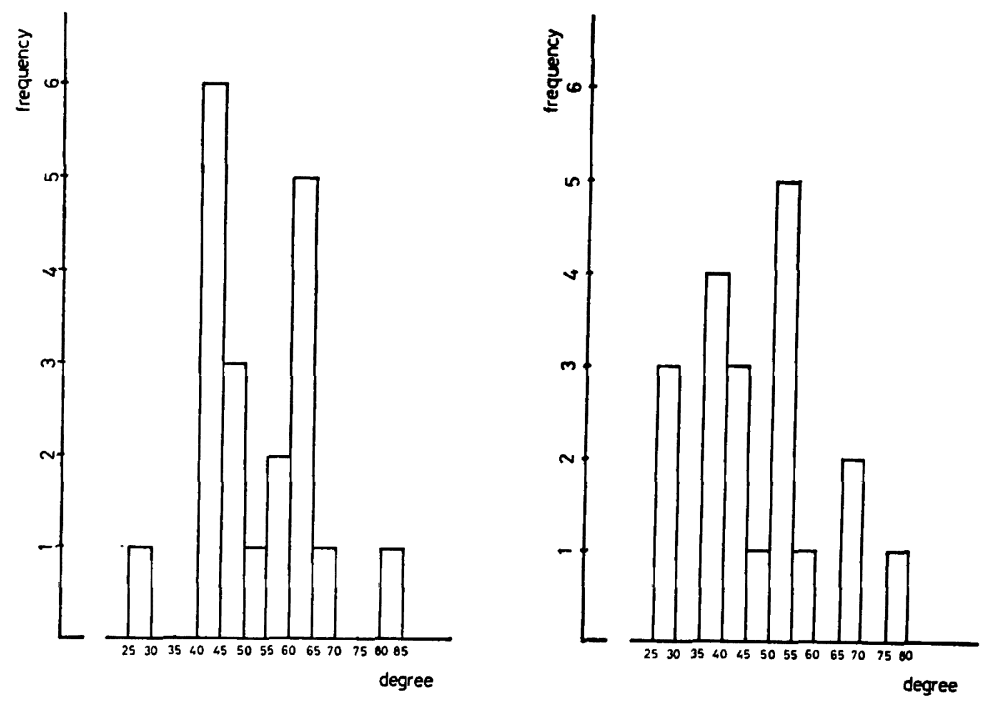

図 14 関節露前壁傾斜度の発現頻度

左 : 成人群, 右 : 小児群

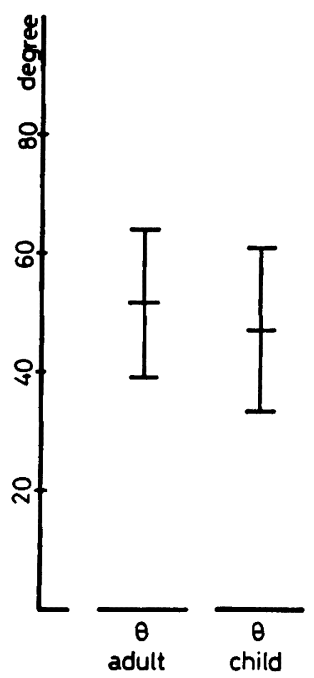

図 15 関節简前壁傾斜度

の測定を行った.

1) 咬頭嵌合位

$\mathrm{Pd}$ は, 成人群で最大 $3.1 \mathrm{~mm}$, 最小 $1.1 \mathrm{~mm}$, 平均 $1.96 \mathrm{~mm}$, 標準偏差 $0.48 \mathrm{~mm}$ であり, 小児群では最大 $2.3 \mathrm{~mm}$, 最小 $0.8 \mathrm{~mm}$, 平均 $1.64 \mathrm{~mm}$, 標準偏差 0.45 $\mathrm{mm}$ であった.

$\mathrm{Rd}$ は, 成人群で最大 $3.9 \mathrm{~mm}$, 最小 $1.6 \mathrm{~mm}$, 平均 $2.69 \mathrm{~mm}$, 標準偏差 $0.70 \mathrm{~mm}$ であり，小児群では最大 $4.4 \mathrm{~mm}$, 最小 $1.8 \mathrm{~mm}$, 平均 $3.01 \mathrm{~mm}$, 標準偏差 0.70
表 6 咬頭嵌合位における関節窝前壁および後壁 と顆頭との最接近距離測定結果

\begin{tabular}{|c|c|c|c|c|c|}
\hline i.p & & adult & i.p & & child \\
\hline & $P d$ & Rd & & Pd & Rd \\
\hline Ar & 1.9 & 2.3 & $a r$ & 1.8 & 3.5 \\
\hline $\mathrm{Al}$ & 1.1 & 2.7 & al & 1.0 & 3.2 \\
\hline $\mathrm{Br}$ & 1.2 & 1.9 & br & 1.6 & 2.6 \\
\hline $\mathrm{Bl}$ & 1.5 & 1.6 & bl & 2.2 & 2.7 \\
\hline $\mathrm{Cr}$ & 1.5 & 2.0 & cr & 1.9 & 1.8 \\
\hline $\mathrm{Cl}$ & 2.0 & 2.2 & cl & 1.4 & 3.3 \\
\hline $\mathrm{Dr}$ & 1.8 & 3.9 & $\mathrm{dr}$ & 0.9 & 2.7 \\
\hline $\mathrm{Dl}$ & 2.1 & 3.6 & dl & 1.6 & 3.4 \\
\hline $\mathrm{Er}$ & 1.9 & 1.9 & er & 1.8 & 3.7 \\
\hline $\mathrm{El}$ & 2.0 & 2.8 & el & 1.7 & 3.2 \\
\hline $\mathrm{Fr}$ & 3.1 & 3.4 & fr & 1.5 & 3.7 \\
\hline $\mathrm{Fl}$ & 2.2 & 2.7 & $\mathrm{fl}$ & 2.2 & 4.4 \\
\hline $\mathrm{Gr}$ & 2.4 & 2.7 & $\mathbf{g r}$ & 0.8 & 2.9 \\
\hline Gl & 1.8 & 2.9 & $\mathrm{gl}$ & 1.6 & 1.9 \\
\hline $\mathrm{Hr}$ & 2.6 & 2.7 & $\mathrm{hr}$ & 1.6 & 2.2 \\
\hline $\mathrm{HI}$ & 2.2 & 1.6 & hl & 2.0 & 2.1 \\
\hline Ir & 2.5 & 3.6 & ir & 2.2 & 3.0 \\
\hline Il & 2.2 & 3.2 & il & 1.0 & 2.4 \\
\hline $\mathrm{Jr}$ & 1.5 & 3.6 & jr & 2.3 & 3.5 \\
\hline $\mathrm{JI}$ & 1.7 & 2.5 & $\mathrm{jl}$ & 1.7 & 3.9 \\
\hline M & 1.96 & 2.69 & $M$ & 1.64 & 3.01 \\
\hline $\mathrm{SD}$ & 0.48 & 0.70 & SD & 0.45 & 0.70 \\
\hline $\max$ & 3.1 & 3.9 & $\max$ & 2.3 & 4.4 \\
\hline $\min$ & 1.1 & 1.6 & $\min$. & 0.8 & 1.8 \\
\hline
\end{tabular}




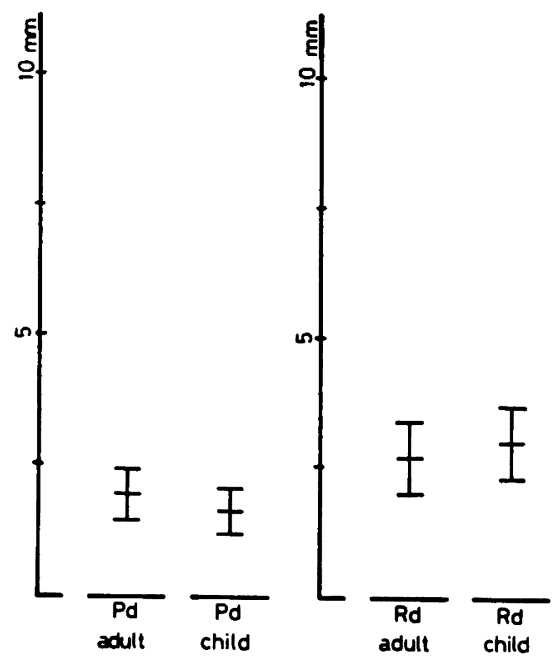

図 16 咬頭嵌合位における関節窩前壁および後 壁と顆頭との最接近距離

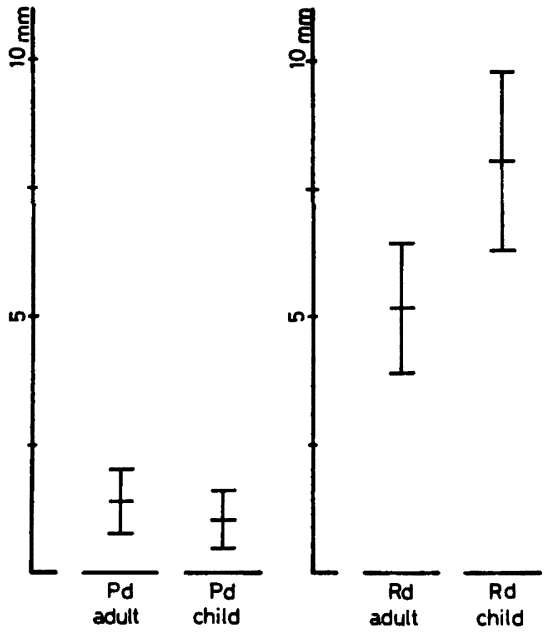

図 17 非作業側における関節禽前壁および後壁 と顆頭との最接近距離

mm であった（表 6, 図 16).

2) 非作業側

Pd は, 成人群で最大 $2.7 \mathrm{~mm}$, 最小 $0.3 \mathrm{~mm}$, 平均 $1.40 \mathrm{~mm}$, 標準偏差 $0.64 \mathrm{~mm}$ であり，小児群では最大 $2.0 \mathrm{~mm}$, 最小 $0.3 \mathrm{~mm}$, 平均 $1.05 \mathrm{~mm}$, 標準偏差 0.56 $\mathrm{mm}$ であった.

Rd は, 成人群で最大 $8.4 \mathrm{~mm}$, 最小 $3.0 \mathrm{~mm}$, 平均 $5.18 \mathrm{~mm}$, 標準偏差 $1.27 \mathrm{~mm}$ であり, 小児群では最大 $11.8 \mathrm{~mm}$, 最小 $5.9 \mathrm{~mm}$, 平均 $8.08 \mathrm{~mm}$, 標準偏差 1.75
表 7 非作業側における関節窝前壁および後壁と顆 頭との最接近距離測定結果

\begin{tabular}{|c|c|c|c|c|c|}
\hline \multirow[t]{2}{*}{ n.w.s } & & \multirow{2}{*}{$\frac{\text { adult }}{\mathrm{Rd}}$} & \multirow[t]{2}{*}{ n.w.s } & \multicolumn{2}{|r|}{ child } \\
\hline & $\mathrm{Pd}$ & & & $\mathrm{Pd}$ & $\mathrm{Rd}$ \\
\hline Ar & 1.1 & 5.3 & ar & - & - \\
\hline $\mathrm{Al}$ & 0.7 & 4.8 & al & - & - \\
\hline $\mathrm{Br}$ & 0.6 & 8.4 & br & 1.5 & 6.9 \\
\hline $\mathrm{Bl}$ & 1.0 & 4.7 & bl & 1.8 & 7.9 \\
\hline $\mathrm{Cr}$ & 1.7 & 3.8 & cr & 1.2 & 6.3 \\
\hline $\mathrm{Cl}$ & 0.3 & 4.7 & $\mathrm{cl}$ & - & - \\
\hline Dr & 2.3 & 6.9 & $\mathrm{dr}$ & 0.8 & 6.6 \\
\hline Dl & 1.4 & 5.1 & $\mathrm{dl}$ & 1.3 & 9.4 \\
\hline Er & 2.2 & 3.0 & er & - & - \\
\hline $\mathrm{El}$ & 0.8 & 5.9 & el & - & - \\
\hline$F_{r}$ & 2.7 & 4.2 & fr & 0.3 & 11.8 \\
\hline $\mathrm{Fl}$ & 2.0 & 6.5 & fl & - & - \\
\hline $\mathrm{Gr}$ & 1.5 & 4.9 & gr & 0.9 & 8.5 \\
\hline $\mathrm{Gl}$ & - & - & g] & 0.4 & 8.5 \\
\hline $\mathrm{Hr}$ & 1.4 & 5.3 & $\mathrm{hr}$ & 2.0 & 5.9 \\
\hline $\mathrm{Hl}$ & 1.3 & 3.7 & hl & 1.3 & 6.4 \\
\hline Ir & 1.3 & 6.2 & ir & - & - \\
\hline Il & 1.9 & 5.1 & il & - & - \\
\hline $\mathbf{J r}$ & 1.0 & 4.8 & $\mathrm{jr}$ & 0.7 & 9.5 \\
\hline Jl & - & - & jl & 0.4 & 9.2 \\
\hline $\mathbf{M}$ & 1.40 & 5.18 & $\mathrm{M}$ & 1.05 & 8.08 \\
\hline SD & 0.64 & 1.27 & $\mathrm{SD}$ & 0.56 & 1.75 \\
\hline $\max$ & 2.7 & 8.4 & $\max$ & 2.0 & 11.8 \\
\hline $\min$. & 0.3 & 3.0 & $\min$. & 0.3 & 5.9 \\
\hline
\end{tabular}

mm であった（表 7, 図 17).

\section{3. 関節䆓顆頭間空隙の断面積}

咬頭嵌合位および非作業側における関節窩顆頭間空隙 の断面積測定を全域 (whole area), 前方域 (area P), 後 方域 (area R) について行った。

1) 咬頭嵌合位

whole area は, 成人群で最大 $67.0 \mathrm{~mm}^{2}$, 最小 27.6 $\mathrm{mm}^{2}$, 平均 $50.84 \mathrm{~mm}^{2}$, 標準偏差 $12.38 \mathrm{~mm}^{2}$ であり, 小 児群では最大 $88.4 \mathrm{~mm}^{2}$, 最小 $27.4 \mathrm{~mm}^{2}$, 平均 49.34 $\mathrm{mm}^{2}$, 標準偏差 $14.00 \mathrm{~mm}^{2}$ であった.

area $\mathrm{P}$ は, 成人群で最大 $40.1 \mathrm{~mm}^{2}$, 最小 $13.7 \mathrm{~mm}^{2}$, 平均 $25.45 \mathrm{~mm}^{2}$, 標準偏差 $6.56 \mathrm{~mm}^{2}$ であり, 小児群で は最大 $37.7 \mathrm{~mm}^{2}$, 最小 $15.0 \mathrm{~mm}^{2}$, 平均 $24.13 \mathrm{~mm}^{2}$, 標 淮偏差 $6.50 \mathrm{~mm}^{2}$ であった.

area $\mathrm{R}$ は, 成人群で最大 $44.6 \mathrm{~mm}^{2}$, 最小 $12.5 \mathrm{~mm}^{2}$, 平均 $25.39 \mathrm{~mm}^{2}$, 標準偏差 $8.21 \mathrm{~mm}^{2}$ であり, 小児群で 
表 8 咬頭嵌合位における関節窝顆頭間空隙の 断面積測定結果

\begin{tabular}{|c|c|c|c|c|c|c|c|}
\hline \multirow[t]{2}{*}{ i.p } & & adult & \multicolumn{3}{|l|}{ i. p } & \multirow[t]{2}{*}{ child } \\
\hline & area $\mathrm{P}$ & area $\mathrm{R}$ & whole & & area $\mathrm{P}$ & area $\mathrm{R}$ & \\
\hline $\mathrm{Ar}$ & 22.8 & .0 & .8 & ar & 7.7 & .0 & 54.2 \\
\hline Al & 22.5 & 22.2 & 44.7 & al & 23.8 & 25.7 & 49.5 \\
\hline $\mathrm{Br}$ & 16.5 & 16.0 & 32.5 & br & 22.9 & 32.1 & 55.0 \\
\hline $\mathrm{Bl}$ & 20.6 & 15.6 & 36.2 & bl & 25.1 & 18.6 & 43.7 \\
\hline $\mathrm{Cr}$ & 13.7 & 16.2 & 29.9 & cr & 20.4 & 16.7 & 37.1 \\
\hline $\mathrm{Cl}$ & 27.8 & 20.8 & 48.6 & $\mathrm{cl}$ & 17.8 & 17.9 & 35.7 \\
\hline $\mathrm{Dr}$ & 22.0 & 4 & 4.4 & $\mathrm{dr}$ & 17.2 & 31.4 & 48.6 \\
\hline Dl & 32.0 & 30.2 & 62.2 & $\mathrm{dl}$ & 29.5 & 28.9 & 58.4 \\
\hline $\mathrm{Er}$ & 28.9 & 25.5 & 54.4 & er & 21.3 & 28.2 & 49.5 \\
\hline El & 40.1 & 28.7 & 68.8 & el & 34.2 & 15.2 & 49.4 \\
\hline $\mathrm{Fr}$ & 24.6 & 26.5 & 51.1 & fr & 31.4 & 43. & 74.5 \\
\hline $\mathrm{Fl}$ & 30.8 & 2 & 54.5 & fl & 37.7 & 50. & 88.4 \\
\hline $\mathrm{Gr}$ & 30.7 & 25.9 & 56.6 & $\mathrm{gr}$ & 19.9 & 24.4 & 44.3 \\
\hline $\mathrm{Gl}$ & 23.1 & 24.0 & 47.1 & gl & 19.1 & 22.2 & 41.3 \\
\hline $\mathrm{Hr}$ & 34.7 & 31.6 & 66.3 & $\mathrm{hr}$ & 15.0 & 12.4 & 27.4 \\
\hline $\mathrm{Hl}$ & 26.5 & 19.4 & 45.9 & $\mathrm{hl}$ & 20.7 & 15.8 & 36.5 \\
\hline $\mathrm{Ir}$ & 22.4 & 44.6 & 67.0 & ir & 18.8 & 22.7 & 41.5 \\
\hline Il & 28.2 & 32.1 & 60.3 & il & 17.7 & 19.8 & 37.5 \\
\hline $\mathrm{Jr}$ & 25.9 & 25.9 & 51.8 & $\mathrm{jr}$ & 29.7 & 27.9 & 57.6 \\
\hline $\mathrm{Jl}$ & 15.1 & 12.5 & 27.6 & jl & 32.6 & 24.0 & 56.6 \\
\hline M & 25.45 & 25.39 & 50.84 & M & 24.13 & 25.21 & 49.34 \\
\hline SD & 6.56 & 8.21 & 12.38 & SD & 6.50 & 9.34 & 14.00 \\
\hline $\max$ & 40.1 & 44.6 & 67.0 & $\max$. & 37.7 & 50.7 & 88.4 \\
\hline $\min$. & 13.7 & 12.5 & 27.6 & $\min$. & 15.0 & 12.4 & 27.4 \\
\hline
\end{tabular}

$\mathrm{mm}^{2}$

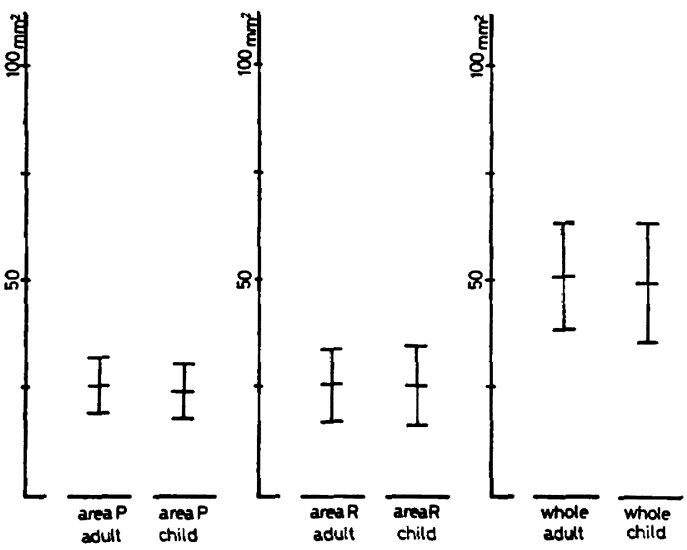

图 18 咬頭嵌合位における関節窩顆頭間空隙の断面積

は最大 $50.7 \mathrm{~mm}^{2}$, 最小 $12.4 \mathrm{~mm}^{2}$, 平均 $25.21 \mathrm{~mm}^{2}$, 標 準偏差 $9.34 \mathrm{~mm}^{2}$ であった（表 8, 図 18).
表 9 非作業側における関節窝顆頭間空㩐の断 面積測定結果

\begin{tabular}{|c|c|c|c|c|c|c|c|}
\hline \multicolumn{2}{|c|}{ n.w.s } & \multicolumn{2}{|r|}{ adult } & \multicolumn{2}{|c|}{ n.w.s } & \multicolumn{2}{|r|}{ child } \\
\hline & area $P$ & area $R$ & whole & & area $\mathbf{P}$ & area $R$ & whole \\
\hline Ar & 24.3 & 35.6 & 59.9 & $\mathrm{ar}$ & 43.8 & 33.5 & 77.3 \\
\hline Al & 24.2 & 33.0 & 57.2 & al & 41.1 & 33.9 & 75.0 \\
\hline $\mathrm{Br}$ & 31.8 & 24.3 & 56.1 & $\mathrm{br}$ & 28.8 & 48.0 & 76.8 \\
\hline $\mathrm{Bl}$ & 22.9 & 25.7 & 48.6 & bl & 34.9 & 22.1 & 57.0 \\
\hline $\mathrm{Cr}$ & 17.8 & 23.4 & 41.2 & cr & 25.6 & 30.0 & 55.6 \\
\hline $\mathrm{Cl}$ & 23.3 & 38.6 & 61.9 & cl & 27.5 & 20.2 & 47.7 \\
\hline $\mathrm{Dr}$ & 35.3 & 50.4 & 85.7 & $\mathrm{dr}$ & 26.8 & 47.6 & 74.4 \\
\hline Dl & 34.1 & 33.0 & 67.1 & $\mathrm{dl}$ & 42.4 & 39.1 & 81.5 \\
\hline Er & 34.5 & 33.3 & 67.8 & er & 33.2 & 34.5 & 67.7 \\
\hline El & 36.1 & 43.5 & 79.6 & el & 43.1 & 14.9 & 58.0 \\
\hline $\mathrm{Fr}$ & 24.2 & 30.3 & 54.5 & fr & 48.0 & 58.5 & 106.5 \\
\hline $\mathrm{Fl}$ & 39.4 & 36.6 & 76.0 & fl & 49.5 & 59.9 & 109.4 \\
\hline $\mathrm{Gr}$ & 30.4 & 36.8 & 67.2 & gr & 34.2 & 30.9 & 65.1 \\
\hline Gl & 32.6 & 30.7 & 63.3 & gl & 35.4 & 32.4 & 67.8 \\
\hline $\mathrm{Hr}$ & 37.6 & 53.0 & 90.6 & $\mathrm{hr}$ & 24.0 & 13.8 & 37.8 \\
\hline $\mathrm{Hl}$ & 24.1 & 32.3 & 56.4 & hl & 32.5 & 24.1 & 56.6 \\
\hline $\mathrm{Ir}$ & 20.3 & 53.1 & 73.4 & ir & 24.0 & 30.7 & 54.7 \\
\hline Il & 31.0 & 40.0 & 71.0 & il & 28.8 & 21.4 & 50.2 \\
\hline $\mathrm{Jr}$ & 22.6 & 32.0 & 54.6 & jr & 46.9 & 33.1 & 80.0 \\
\hline $\mathrm{Jl}$ & 18.6 & 14.8 & 33.4 & jl & 49.7 & 26.0 & 75.7 \\
\hline$M$ & 28.26 & 35.02 & 63.28 & $M$ & 36.01 & 32.73 & 68.74 \\
\hline $\mathrm{SD}$ & 6.71 & 9.78 & 14.12 & SD & 8.86 & 12.80 & 18.00 \\
\hline $\max$. & 39.4 & 53.1 & 90.6 & $\max$. & 49.7 & 59.9 & 109.4 \\
\hline $\min$. & 17.8 & 14.8 & 33.4 & $\min$. & 24.0 & 13.8 & 37.8 \\
\hline
\end{tabular}

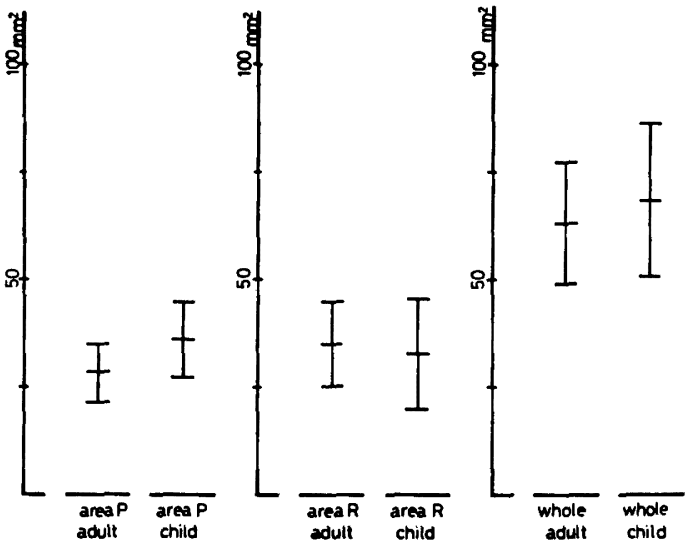

图 19 非作業側にお於る関節窝顆頭間空隙の断面稓

2) 非作業側

whole area は, 成人群で最大 $90.6 \mathrm{~mm}^{2}$, 最小 33.4 $\mathrm{mm}^{2}$, 平均 $63.28 \mathrm{~mm}^{2}$, 標準偏差 $14.12 \mathrm{~mm}^{2}$ であり, 小 
表 10 関節窝最高点を基準とした顆頭頂位測定結果

\begin{tabular}{|c|c|c|c|c|c|c|c|c|c|}
\hline \multicolumn{5}{|r|}{ adult } & \multicolumn{5}{|r|}{ child } \\
\hline & \multicolumn{2}{|c|}{ i. $p$} & \multicolumn{2}{|c|}{ n.w.s } & & \multicolumn{2}{|c|}{ i.p } & \multicolumn{2}{|c|}{ n.w.s } \\
\hline & $\mathbf{x}$ & $\mathbf{y}$ & $\mathbf{x}$ & $y$ & & $\mathbf{x}$ & $\mathbf{y}$ & $\mathbf{x}$ & $y$ \\
\hline $\mathrm{Ar}$ & 0.00 & 1.95 & 2.00 & 4.65 & ar & 0.60 & 2.90 & 5.40 & 6.00 \\
\hline $\mathrm{Al}$ & -0.50 & 2.90 & 1.30 & 4.10 & al & 0.50 & 3.40 & 7.40 & 7.60 \\
\hline $\mathrm{Br}$ & 1.70 & 1.60 & 5.75 & 5.10 & br & 0.80 & 2.50 & 3.50 & 6.00 \\
\hline $\mathrm{Bl}$ & -1.20 & 2.90 & 1.15 & 4.15 & bl & 0.80 & 2.00 & 5.20 & 5.60 \\
\hline $\mathrm{Cr}$ & 0.00 & 1.00 & 2.40 & 2.20 & cr & -1.60 & 3.80 & 2.10 & 5.50 \\
\hline $\mathrm{Cl}$ & 0.00 & 1.35 & 2.90 & 2.40 & cl & 1.40 & 2.90 & 6.00 & 5.80 \\
\hline Dr & 1.00 & 2.90 & 3.10 & 5.90 & $\mathrm{dr}$ & 0.00 & 3.80 & 1.30 & 5.00 \\
\hline DI & 1.40 & 2.45 & 2.40 & 4.90 & $\mathrm{dl}$ & 0.70 & 3.10 & 6.30 & 8.40 \\
\hline Er & 0.75 & 3.00 & 1.70 & 4.70 & er & 0.00 & 4.00 & 6.20 & 6.60 \\
\hline El & 1.20 & 2.70 & 2.40 & 4.75 & el & 2.50 & 2.80 & 8.70 & 6.30 \\
\hline $\mathbf{F r}$ & 0.40 & 3.30 & 0.75 & 4.30 & fr & 0.00 & 4.80 & 5.80 & 8.50 \\
\hline Fl & 1.30 & 2.90 & 2.95 & 3.30 & $\mathrm{fl}$ & 0.80 & 4.20 & 4.60 & 9.80 \\
\hline Gr & 0.00 & 3.10 & 2.15 & 4.85 & $\mathbf{g r}$ & 1.50 & 1.80 & 6.80 & 5.80 \\
\hline Gl & 1.25 & 3.30 & 6.90 & 6.30 & gl & 0.00 & 3.00 & 4.60 & 5.70 \\
\hline $\mathrm{Hr}$ & -0.65 & 2.35 & 2.00 & 5.00 & $\mathbf{h r}$ & 0.00 & 2.30 & 4.30 & 7.20 \\
\hline $\mathrm{Hl}$ & 0.45 & 1.60 & 1.80 & 2.80 & hl & -0.80 & 3.35 & 3.50 & 5.35 \\
\hline Ir & -1.25 & 5.60 & 0.40 & 6.75 & ir & -1.20 & 2.80 & 6.00 & 5.80 \\
\hline Il & -0.80 & 6.00 & 1.05 & 5.65 & il & 0.00 & 1.30 & 7.20 & 5.00 \\
\hline $\mathbf{J r}$ & 0.00 & 2.70 & 4.40 & 3.50 & jr & 0.00 & 2.90 & 6.20 & 5.25 \\
\hline $\mathrm{Jl}$ & 1.35 & 2.25 & 3.40 & 3.10 & jl & 2.30 & 3.10 & 8.20 & 5.75 \\
\hline M & 0.320 & 2.793 & 2.545 & 4.420 & $\mathrm{M}$ & 0.415 & 3.038 & 5.465 & 6.348 \\
\hline $\mathrm{SD}$ & 0.905 & 1.221 & 1.616 & 1.252 & SD & 1.025 & 0.840 & 1.896 & 1.301 \\
\hline $\max$ & 1.70 & 6.00 & 6.90 & 6.75 & $\max$ & 2.50 & 4.80 & 8.70 & 9.80 \\
\hline $\min$. & -1.25 & 1.00 & 0.40 & 2.20 & $\min$. & -1.60 & 1.30 & 1.30 & 5.00 \\
\hline
\end{tabular}

児群では最大 $109.4 \mathrm{~mm}^{2}$, 最小 $37.8 \mathrm{~mm}^{2}$, 平均 68.74 $\mathrm{mm}^{2}$, 標準偏差 $18.00 \mathrm{~mm}^{2}$ であった.

area $P$ は, 成人群で最大 $39.4 \mathrm{~mm}^{2}$, 最小 $17.8 \mathrm{~mm}^{2}$, 平均 $28.26 \mathrm{~mm}^{2}$, 標準偏差 $6.71 \mathrm{~mm}^{2}$ であり，小児群で は最大 $49.7 \mathrm{~mm}^{2}$, 最小 $24.0 \mathrm{~mm}^{2}$, 平均 $36.01 \mathrm{~mm}^{2}$, 標 準偏差 $8.86 \mathrm{~mm}^{2}$ であった.

area $\mathrm{R}$ は, 成人群で最大 $53.1 \mathrm{~mm}^{2}$, 最小 $14.8 \mathrm{~mm}^{2}$, 平均 $35.02 \mathrm{~mm}^{2}$, 標準偏差 $9.78 \mathrm{~mm}^{2}$ であり，小児群で は最大 $59.9 \mathrm{~mm}^{2}$, 最小 $13.8 \mathrm{~mm}^{2}$, 平均 $32.73 \mathrm{~mm}^{2}$, 標 準偏差 $12.80 \mathrm{~mm}^{2}$ であった（表 9 , 図 19).

\section{4. 各額位における顆頭頂の位置}

下䫑骨枝後縁豊隆部を結んだ線を基準として最も高い 点を顆頭頂とみなし，関節窝最高点を基準とした前後お よび上下的な位置すなわち $\mathrm{x}$ と $\mathrm{y}$ についての測定結果 はつぎのとおりであった。
1）咬頭嵌合位

$\mathrm{x}$ は, 成人群で最大 $1.70 \mathrm{~mm}$, 最小 $-1.25 \mathrm{~mm}$, 平均 $0.320 \mathrm{~mm}$ ，標準偏差 $0.905 \mathrm{~mm}$ であり，小児群では最 大 $2.50 \mathrm{~mm}$, 最小 $-1.60 \mathrm{~mm}$, 平均 $0.415 \mathrm{~mm}$, 標準偏差 $1.025 \mathrm{~mm}$ であった.

$\mathrm{y}$ は, 成人群で最大 $6.00 \mathrm{~mm}$, 最小 $1.00 \mathrm{~mm}$, 平均 $2.793 \mathrm{~mm}$ ，標準偏差 $1.221 \mathrm{~mm}$ であり，小児群では最 大 $4.80 \mathrm{~mm}$, 最小 $1.30 \mathrm{~mm}$, 平均 $3.038 \mathrm{~mm}$, 標準偏差 $0.840 \mathrm{~mm}$ であった（表 10 , 図 $20,21,22$ ).

2）非作業側

x は, 成人群で最大 $6.90 \mathrm{~mm}$, 最小 $0.40 \mathrm{~mm}$, 平均 $2.545 \mathrm{~mm}$ ，標準偏差 $1.616 \mathrm{~mm}$ であり，小児群では最 大 $8.70 \mathrm{~mm}$, 最小 $1.30 \mathrm{~mm}$, 平均 $5.465 \mathrm{~mm}$, 標淮偏差 $1.896 \mathrm{~mm}$ であった.

$\mathrm{y}$ は, 成人群で最大 $6.75 \mathrm{~mm}$, 最小 $2.20 \mathrm{~mm}$, 平均 $4.420 \mathrm{~mm}$ ，標準偏差 $1.252 \mathrm{~mm}$ であり，小児群では最 


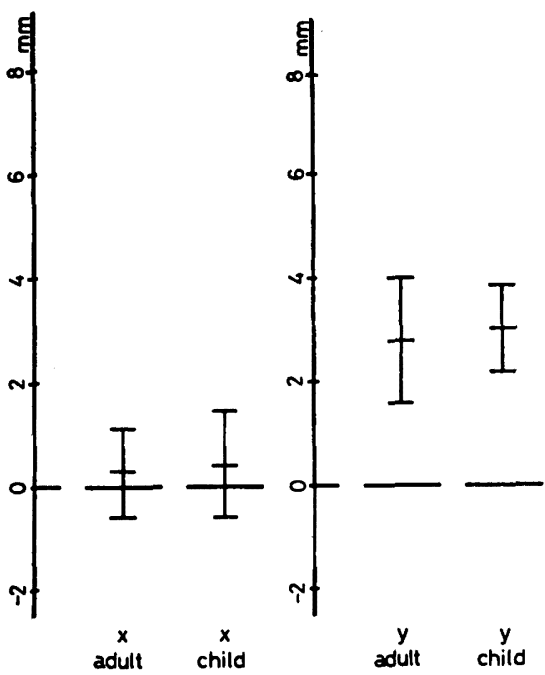

图 20 咬頭嵌合位における関節窝最高点を基準とし た前後的な距離 $\mathbf{x}$ と上下的な距離 $\mathbf{y}$

$$
\text { 左: } x \text {, 右 : } y
$$

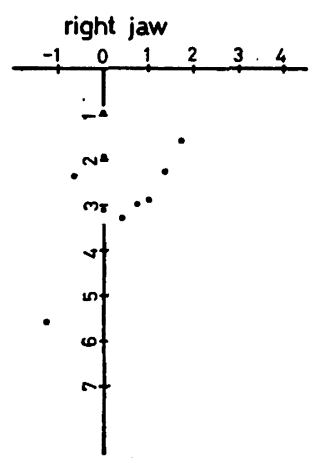

i.p

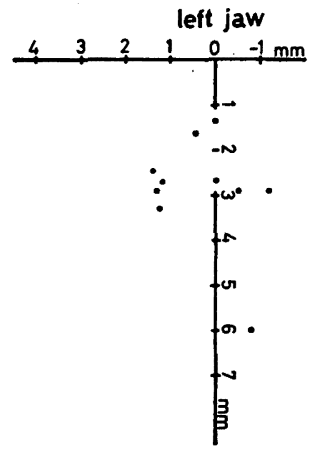

图 21 成人群の咬頭嵌合位における顆頭頂の位㯰
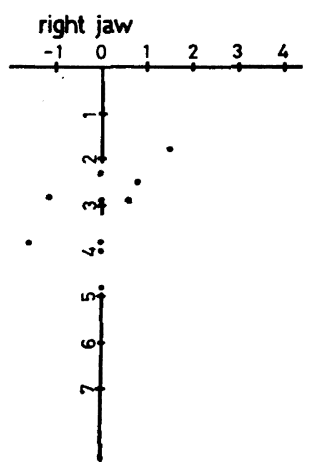

i.p
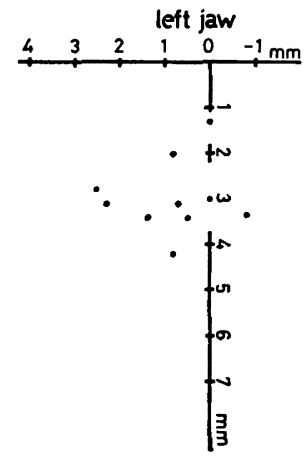

図 22 小児群の咬頭嵌合位における顆頭頂の位直

大 $9.80 \mathrm{~mm}$, 最小 $5.00 \mathrm{~mm}$, 平均 $6.348 \mathrm{~mm}$, 標準偏 差 $1.301 \mathrm{~mm}$ であった（表 10, 図 23).

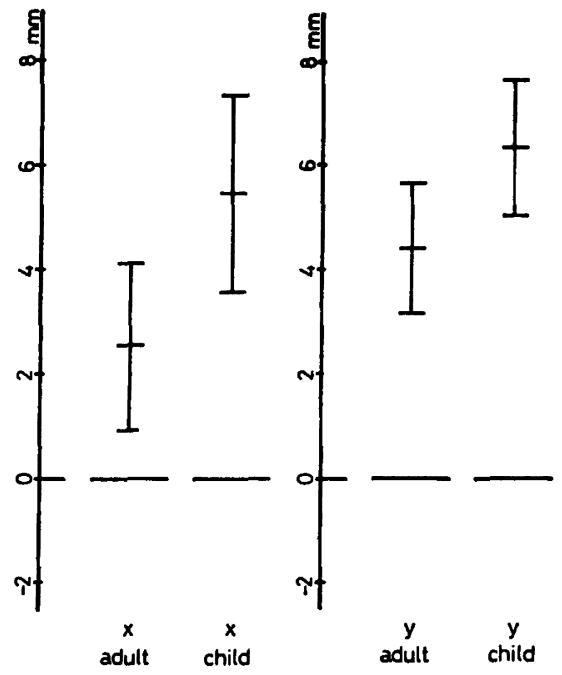

图 23 非作業側における関節窩最高点を基準とした 前後的な距離 $\mathrm{x}$ と上下的な距離 $\mathrm{y}$

$$
\text { 左: } \mathrm{x} \text {, 右: } \mathrm{y}
$$

\begin{tabular}{|c|c|c|c|}
\hline & adult & & child \\
\hline & n.w.s $(\theta)$ & & n.w.s $(\theta)$ \\
\hline $\mathrm{Ar}$ & 53 & ar & 33 \\
\hline $\mathrm{Al}$ & 34 & al & 31 \\
\hline $\mathrm{Br}$ & 41 & br & 52 \\
\hline $\mathrm{Bl}$ & 28 & bl & 39 \\
\hline $\mathrm{Cr}$ & 27 & cr & 25 \\
\hline $\mathrm{Cl}$ & 20 & $\mathrm{cl}$ & 32 \\
\hline $\mathrm{Dr}$ & 55 & $\mathrm{dr}$ & 43 \\
\hline $\mathrm{Dl}$ & 68 & $\mathrm{dl}$ & 43 \\
\hline $\mathrm{Er}$ & 61 & er & 23 \\
\hline $\mathrm{El}$ & 60 & el & 29 \\
\hline $\mathbf{F r}$ & 71 & $\mathrm{fr}$ & 33 \\
\hline $\mathrm{Fl}$ & 14 & fl & 56 \\
\hline $\mathrm{Gr}$ & 39 & gr & 37 \\
\hline GI & 28 & gl & 30 \\
\hline $\mathrm{Hr}$ & 45 & $\mathrm{hr}$ & 49 \\
\hline $\mathrm{Hl}$ & 42 & hl & 25 \\
\hline Ir & 35 & ir & 23 \\
\hline Il & -11 & il & 27 \\
\hline $\mathrm{Jr}$ & 23 & $\mathrm{jr}$ & 21 \\
\hline $\mathrm{Jl}$ & 11 & $\mathrm{jl}$ & 24 \\
\hline $\mathbf{M}$ & 37.2 & $\mathbf{M}$ & 33.8 \\
\hline $\mathrm{SD}$ & 20.7 & SD & 10.3 \\
\hline $\max$. & 71 & $\max$ & 56 \\
\hline $\min$. & -11 & $\min$. & 21 \\
\hline
\end{tabular}

表 11 非作業側顆路傾斜度測定結果 


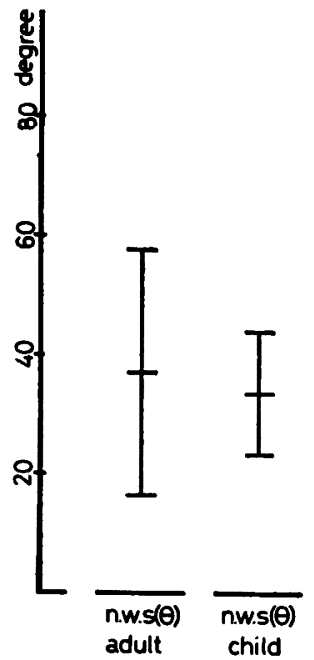

図 24 非作業側顆路傾斜度

\section{5. 顆頭頂の移動}

つぎにあげる各被験者群における顆頭頂の移動につい
ての調查結果はつぎのとおりである.

1）成人群における咬頭嵌合位から非作業側にいたる 変化

咬頭嵌合位から非作業側にいたる顆頭頂の動きを直線 とするとその移動距離 は, 最大 $6.40 \mathrm{~mm}$, 最 小 1.06 $\mathrm{mm}$, 平均 $2.900 \mathrm{~mm}$, 標準偏差 $1.307 \mathrm{~mm}$ であり，ほと んどの場合前下方へ大きな動きを示したが, 被験者 $\mathrm{i} の$ 左側のように前上方へ移動する特殊例が 1 例みられた。

また, この運動時の顆頭頂の移動により生した $\mathrm{F}-\mathrm{H}$ 平面に対する傾斜角度は, 最大 71 度, 最小-11 度, 平 均 37.2 度, 標準偏差 20.7 度であった（表 11, 図 24, 25).

2）小児群における咬頭嵌合位から非作業側にいたる 変化

咬頭嵌合位から非作業側にいたる移動 距離は, 最大 $8.10 \mathrm{~mm}$, 最小 $1.77 \mathrm{~mm}$, 平均 $6.130 \mathrm{~mm}$, 標準偏差 $1.550 \mathrm{~mm}$ であり, すべてにおいて前下方へ大きな動き を示した.

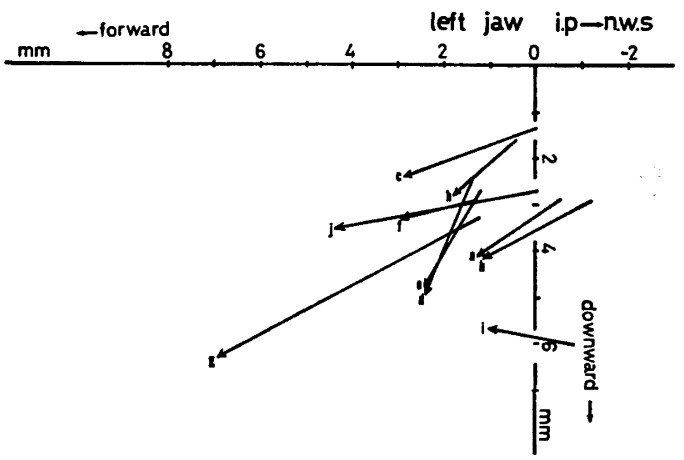

図 25 成人群における咬頭嵌合位から非作業側への顆頭頂の移動
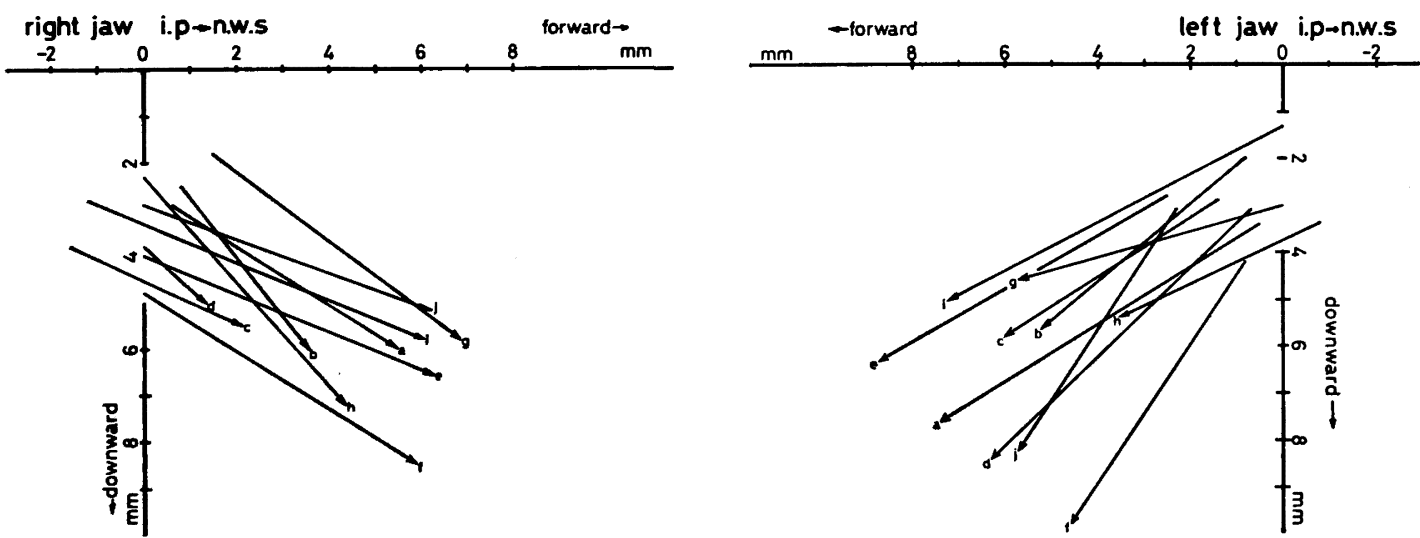

図 26 小児群における咬頭嵌合位から非作業側への顆頭頂の移動 
$162-814$

また,この運動時の顆頭頂の移動により生じた F-H 平面に対する傾斜角度は, 最大 56 度, 最小 21 度, 平均 33.8 度，標準偏差 10.3 度であった（表 11 ，図 24，26）.

\section{IV. 考察}

近年, T.M.J. 付近の形態的調查执よび下頷運動に関 する研究は, 様々な新しい測定方法が考案され, その結 果, 構造や動きなどが明らかにされつつある.しかし, これらの研究はほとんどが成人を対象として行われてき ており，その前後すなわち小児や老人に関するものはと ぼしく，とりわけ小児においてはほとんどみられないの が現状である.T.M.J. の形態拉よびそれに影響を受け るであろう下頡運動は同一個体に拉いても小児, 成人, 老人へと増齢するに従って当然変化していくものと思わ れる.

そこで今回は，すでに調查を行った成人に関する情報 をもとに，小児における調查結果を対比させながら，小 児と成人の T.M.J. 付近の形態と顆頭の挙動について比 較研究を行った.

\section{1. 関節窩の形態について}

乳歯列期より成人にいたる間の関節窩の形態的変化に ついての調查は森永 ${ }^{24,25)}$ (1942 年), 小池 ${ }^{26)}$ (1970 年), 黒田 ${ }^{27)}$ (1974 年) などが行っている.

森永 ${ }^{24,25)}$ は, 日本人顎関節の脱灰標本を用いてその肉 眼的形態ならびに組織学的調査を行っている.すなわ ち, 乳幼児期以後においては, 急速な関節窝の改変はみ られないが, 少青年期においてはきわめてわずかに, 主 として関節結節部の骨性ならびに軟骨性膨隆によって前 後径ならびに深度が増加する. また, 関節結節の発育に ついては，5歳になるとかなりの程度にまで発育しほぼ 成人のそれに近い形態となると述べている.

小池 ${ }^{26)}$ はインド人の乳歯列, 混合歯列の頭蓋骨を用 い, 頭蓋を眼耳平面に固定した後, 弾性印象剤で下䫟窩 とその周辺を印象した石膏模型に等高線を描記する方法 で観察を行っている.この結果, 下䫑窩の大きさは乳歯 出旡時期には出龈前の $1.2 \sim 1.3$ 倍前後であり, 永久歯 出龈に伴い出龈前の $1.4 \sim 1.5$ 倍前後となるが，その後 永久歯出龈完了まで成曼変化はみられない，すなわち， 歯の出敬良する時期に下影窩の大きさは定まってしまうと している. また，関節結節は乳歯が出撂しはじめた時と 中切歯側切歯第 1 大臼歯が出莭しはじめた時, さらに永 久歯全部の出飺が完了した時期に著しく変化するとして
27 巻 4 号 (1983)

おり,さらに, 関節結節の中央部の高さの発育率は, 乳歯

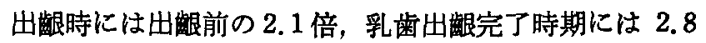
倍, 永久蒾出䟼時期には 3.1 倍である. しかし，中切歯 側切歯第 1 大田歯出根時期には, さらに著しい発育を示 し出跟前の 4 倍である. しかし，その後の発育変化はみ られないとしている。

黒田 ${ }^{27)}$ はインド人小児ならびに成人の頭蓋骨を使用 し，下顎窝の梁さについて計測を行っている，すなわ ち, 眼耳平面と平行で, 下頭窩最深点より関節結節突出 点までの高さを下效裔の樑さとした場合，混合歯列前期 では乳歯列の 1.3 倍前後, 混合歯列中期で乳歯列の $1.3 \sim 1.4$ 倍となり, 以後永久歯列までほほ同じ大きさ である.しかし，成人では著しく発育し乳歯列の 1.7 倍 になると報告している。

われわれの関節窩の形態に関する表現法としては，関 節窝前方部の大きさと関節窩前壁の傾斜度の 2 つを求め た. 前後的な距離 $\mathrm{fl}$ は成人群で平均 $10.610 \mathrm{~mm}$, 小児 群では平均 $10.775 \mathrm{~mm}$ であり, 上下的な距離 $\mathrm{fd}$ は, 成人群で平均 $7.365 \mathrm{~mm}$, 小児群では平均 $6.990 \mathrm{~mm}$ で あった. これらの結果から前後的な距離は成人群より小 児群の方がわずかに大きい値となっている，また，上下 的な距離は成人群が小児群よりあわずかに大きい值を呈 しているが有意差は認められない.

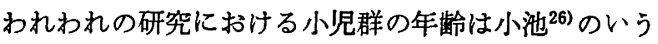
中切歯側切歯第 1 大臼歯出粮時期と永久歯出龈完了時期 の間で，かつ前者に近い時期であると思われる、また，

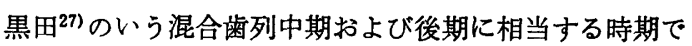
あると思われる. 以上の結果から，すでに中切歯側切歯 第 1 大臼歯の萌出が完了している小児群と成人群の間に は，関節窩の大きさにおいては著変はみられない。すな わち, 中切歯側切歯第 1 大臼歯の萌出により関節窩の大 きさはほぼ定まってしまうものと考えられる.つぎに関 節窩前壁の傾斜度については, 関節䆚前壁における最高 点最低点間の曲線部分を 4 分割し, 最高点および最低点 よりそれぞれ中央寄り $1 / 4$ の 2 点を結んだ直線をもって 曲線部中央の平均的傾斜度とみなした場合の $\mathrm{F}-\mathrm{H}$ 平面 に対する角度を測定した. 成人群は平均で 51.8 度, 小児 群では平均 47.3 度であり, 成人群が 4.5 度大きい傾 斜 度となっている．われわれの測定方法とややその基淮を 異にしているが，小池 ${ }^{26)}$ の報告によれば関節結節と裔底 中央結合線の眼耳平面となす角は乳歯出龈時には 20 度 で出跟前の角度である 10.5 度前後と比較して 2 倍であ るとしている. また, その後の発育は緩徐となり, 乳歯 列弓完成時で 22 度, 永久歯出擳時で 24 度である. しか 


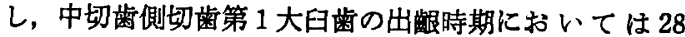
度とやや大きくなり出兓前の 2.6 倍となるがその後の変 化は少ない，しかし，永久歯出跟完了時においては 32 度と出碳前の 3.1 倍となり中切歯側切歯第 1 大白歯の出 敬時期と永久歯出莭完了時との角度差は 4 度であると し,われわれの測定結果 4.5 度と近似した值を示してい る.このように関節窩前壁の傾斜度は小児群よりも成人 群がわずかではあるが大きな值を示したことは関節窝前 方部の前後的な距離 $\mathrm{fl}$ および上下的な距離 fd との比 $\mathrm{fd} / \mathrm{fl}$ が成人群で 0.694，小児群では 0.648でありこれが 影響してるものと思われる，さらに関節窝前壁の警曲状 態の変化も一因たりうると思われる.すなわち図 27 に 示すように小児群においては関節前壁がなす～状形態は なだらかな曲線を描いているものが多いが，成人群にな ると $\mathrm{S}$ 状曲が強くなっているものが多い.

\section{2. 咬頭嵌合位における顆頭の位置について}

黒田 ${ }^{27)}$ は側方よりみた下䫟頭中央突出点の下額窩最哚 点に対する位置について報告を行っているが，これによ ると，外方よりみて中央突出点の下顎窝側縁に投影され た点の側縁最深点に対する位置は，乳歯列，混合歯列で は $65 \%$ 前後が一致し，残り大部分は最深点の後方 2.0 $\mathrm{mm}$ 以内とし, 永久歯列, 成人においては一致するもの がさらに多く $80 \%$ 前後をしめるとしている。これは下 顎窝内において下䫑頭中央突出点怯小児に比較して成人 が前方に位置していることを意味していると思われる.

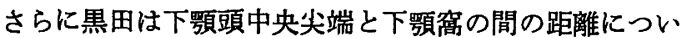
てつぎのように報告している，下堮頭中央尖端と下頡窩 の間の距離は，左右側とも乳歯列より混合歯列後期まで は $1.0 \mathrm{~mm}$ 以内が $90 \%$ 前後をしめるが, 永久歯列では 1.0〜1.5 mm がほとんどをしめ, 成人ではさらに 1.0 $2.0 \mathrm{~mm}$ が $80 \%$ 前後をしめる。 また，平均值において も乳歯列で $0.5 \mathrm{~mm}$, 混合歯列で $0.6 \sim 0.7 \mathrm{~mm}$, 永久歯 列で $1.0 \sim 1.1 \mathrm{~mm}$ 前後, 成人では $1.4 \mathrm{~mm}$ となり, 成 長に伴って増大し, 特に混合歯列後期より永久歯列を一 て成人にいたる時に著明であるとしている．これは下頻 窩内における下額頭中央尖端の位置が, 成人は小児と比 較して下方にあることを意味しているものと思われる。

また Alan High ${ }^{21)}$ は，われかれが使用している頭部 規格断層 X線撮影装置と同し Quint X-ray Sectograph を用いて各年踚別による関節窝における顆頭の位置につ いて報告している。これによれば，男女とも 16 歳より 以前においては顆頭が関節䆻の前方に位置しているが, 16 䠞から 18 歳の間に顆頭は関節窝の中央に近うくとし

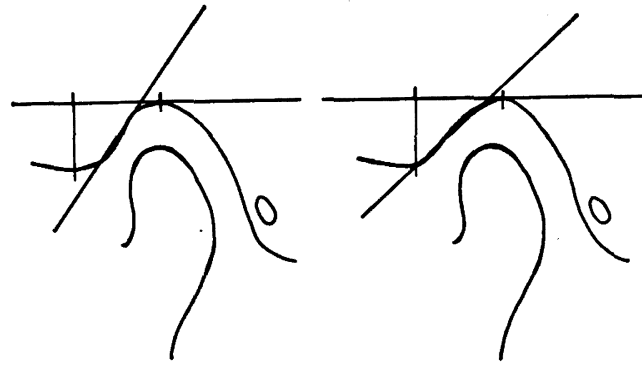

図 27 成人群と小児群における関節前壁 $\mathrm{s}$ 状形態の相違 左：成人群，右：小児群

表 12 関節窝前壁一顆頭最接近距離之関節窝後 壁一顆頭最接近距離の対比：Pd/Rd

\begin{tabular}{|c|c|c|c|c|c|}
\hline \multicolumn{3}{|r|}{ adult } & \multicolumn{3}{|r|}{ child } \\
\hline & i. $p$ & n.w.s & & i.p & n.w.s \\
\hline $\mathrm{Ar}$ & 82.6 & 20.8 & ar & 51.4 & - \\
\hline Al & 40.7 & 14.6 & al & 31.3 & - \\
\hline $\mathrm{Br}$ & 63.2 & 7.1 & br & 61.5 & 21.7 \\
\hline $\mathrm{Bl}$ & 93.8 & 21.3 & bl & 81.5 & 22.8 \\
\hline $\mathrm{Cr}$ & 75.0 & 44.7 & $\dot{c} \mathbf{r}$ & 105.6 & 19.0 \\
\hline $\mathrm{Cl}$ & 90.9 & 6.9 & cl & 42.4 & - \\
\hline $\mathrm{Dr}$ & 46.2 & 33.3 & $\mathrm{~d} \mathbf{r}$ & 33.3 & 12.1 \\
\hline $\mathrm{Dl}$ & 58.3 & 27.4 & $\mathrm{dl}$ & 47.1 & 13.8 \\
\hline $\mathrm{Er}$ & 100.0 & 73.3 & er & 48.6 & - \\
\hline $\mathrm{El}$ & 71.4 & 13.6 & el & 53.1 & - \\
\hline $\mathbf{F r}$ & 91.2 & 64.3 & fr & 40.5 & 2.5 \\
\hline Fl & 81.5 & 30.8 & fl & 50.0 & - \\
\hline $\mathrm{Gr}$ & 88.9 & 30.6 & gr & 27.6 & 10.6 \\
\hline $\mathrm{Gl}$ & 62.1 & - & gl & 84.2 & 4.7 \\
\hline $\mathrm{Hr}$ & 96.3 & 26.4 & $\mathrm{hr}$ & 72.7 & 33.9 \\
\hline $\mathrm{HI}$ & 137.5 & 35.1 & hl & 95.2 & 20.3 \\
\hline $\mathrm{I} \mathbf{r}$ & 69.4 & 21.0 & ir & 73.3 & - \\
\hline Il & 68.8 & 37.3 & il & 41.7 & - \\
\hline $\mathrm{Jr}$ & 41.7 & 20.8 & jr & 65.7 & 7.4 \\
\hline $\mathrm{Jl}$ & 68.0 & - & jl & 43.6 & 4.3 \\
\hline $\mathbf{M}$ & 74.38 & 29.41 & M & 57.52 & 14.43 \\
\hline SD & 22.87 & 17.59 & SD & 21.78 & 9.38 \\
\hline $\max$. & 137.5 & 73.3 & $\max$ & 105.6 & 33.9 \\
\hline $\min$. & 40.7 & 6.9 & $\min$. & 27.6 & 2.5 \\
\hline
\end{tabular}

ている.

われわれは関節窝内における顆頭の位置を表現する方 法として，関節窩壁と顆頭との最接近距離，関節窝顆頭 間空隙の断面積および顆頭頂の位置について測定を行っ た. まず，関節窩壁と顆頭との最接近距離については， $\mathrm{Pd}$ (関節窩前壁と顆頭との最も接近した距離)と Rd (関 

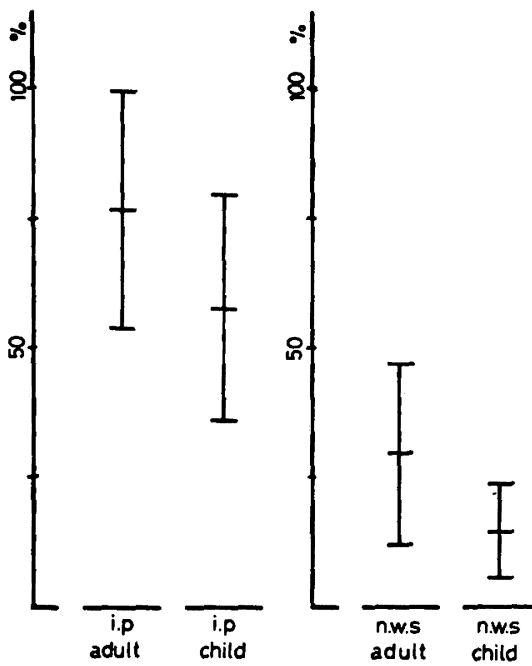

图 28 関節窝前壁一顆頭最接近距離と関節窝後壁一 顆頭最接近距離の対比：Pd/Rd

節窩後壁と顆頭との最も接近した距離）の測定を行い， $\mathrm{Pd}$ は成人群で平均 $1.96 \mathrm{~mm}$, 小児群では平均 $1.64 \mathrm{~mm}$ であり，Rd 江成人群で平均 $2.69 \mathrm{~mm}$ ，小児群では平均 $3.01 \mathrm{~mm}$ という結果であり, 小児群注成人群と比較し て Pd が小さく Rd が大きいことがわかる.このように これらの結果から，咬頭嵌合位において小児の顆頭は成 人に比べて前方に寄っていることが判明した。 さらに $\mathrm{Pd}$ と Rd との比 $\mathrm{Pd} / \mathrm{Rd}$ は表 12 および図 28 の示すよう に，值が小さいほど顆頭が前方に位置していることを意 味しているので, 前述の関係がより明白汇理解されるも のと思われる.

つぎに，関節窩顆頭間空隙の断面積についての調查の 結果, area $P$ (関節墖顆頭間空隙の前方域) は成人群で 平均 $25.45 \mathrm{~mm}^{2}$, 小児群では平均 $24.13 \mathrm{~mm}^{2}$ であり， area R (関節窩顆頭間空隙の後方域) 注成人 群 で平均 $25.39 \mathrm{~mm}^{2}$ ，小児群では平均 $25.21 \mathrm{~mm}^{2}$ であった. area $\mathrm{P}$ は小坚群が成人群より小さな值を示し, area R は両者 ともほぼ同じ值を示した. このように, area P が小児群 で小さな值を示したことは，小児群における関節窩内の 顆頭の位置が前方に位置していることをさらに裹ゔけて いるものと思われる.

顆頭頂の位置については，関節窝最深点を基準として 前後的な位置である $\mathrm{x}$ と上下的な位置である y につい て測定を行い, $x$ は成人群で平均 $0.320 \mathrm{~mm}$, 小児群では 平均 $0.415 \mathrm{~mm}, \mathrm{y}$ は成人群で平均 $2.793 \mathrm{~mm}$, 小児群で は平均 $3.038 \mathrm{~mm}$ という結果を得た. $\mathrm{x}, \mathrm{y}$ ともに小肾群
27 巻 4 号 (1983)

が成人群よりも大きな値を示しており， $\mathrm{x}$ が大きいほど 顆頭は前方に位置することを示し，y が大きいほど顆頭 は下方に位置することを表しているので，小児群の顆頭 の位置は成人群と比較して前下方に存在することにな る. したがって，小児群の顆頭頂は成人群の顆頭頂より 前方へ $0.095 \mathrm{~mm}$, 下方へ $0.245 \mathrm{~mm}$ の位㯰にあり, 直 線距離で $0.263 \mathrm{~mm}$ 前下方に位渎することになる。

以上のような調查結果から，小児群の顆頭の位置は成 人群より関節窝内において前下方に存在することが判明 したが，これは，われわれと同じように頭部規格断層X 線撮影法により研究を行った Alan $\mathrm{High}^{21)}$ の報告と大 略一致するが，乾燥頭蓋骨を用いた黒田 ${ }^{27)}$ の報告とは一 致しない面もみられた.

3. 側方運動時における非作業側顆頭の動きについて 側方運動における非作業側顆頭頂の動きは，成人群の 場合前上方一移動する特殊な 1 例がみられたが，この特 殊例以外はほぼ前下方への動きを示している．また，小 児の場合はすべての被験者において前下方への大きな動 きを示した. この両者の顆頭頂の動きを $\mathrm{F}-\mathrm{H}$ 平面に対 する傾斜角度と移動距離について検討してみると，傾斜 角度は成人群に比較して小児群は平均値で 3.4 度 小さ く，移動距離は小児群が成人群より平均值で $3.230 \mathrm{~mm}$ 大きくなっている．したがって，小児群の非作業側顆頭 頂の動きは成人群より傾斜角度は小さいが移動距離は大 きくなっているといえよう．さらに成人および小児にお ける下蝒運動の相違もこれらの結果に影響をあたえてい るものと思われる. すなわち, side shift value の差が 存在しなければ移動距離の違いを呈すことは考えられな 、ところである. したがって T.M.J. 付近のみならず下 顎運動の全相を調查することがまたれるものと考える.

さて，一般的に関節窝内の関節頭の動きは関節窝内壁 の構造的影響を受けながら行われるものと考えられる が，顎関節のような関節窩顆頭間空隙が比較的大きいも のにあっては構造的な影響が強く現れなくなるであろう ことは想像に難くない，われわれの研究結果からもこの ことがうかがえる，すなわち，関節窝前壁の傾斜度およ び非作業側顆頭の傾斜度はともに成人群が小児群より大 きく，各々 4.5 度および 3.4 度となっている.このよう な傾向は顎関節の関節としての特殊性を表していると思 われる。

つぎに Pd および Rd について成人群と小児群を比較 してみると，Pd は成人群で平均 $1.40 \mathrm{~mm}$ ，小児群では 平均 $1.05 \mathrm{~mm}, \mathrm{Rd}$ は成人群で平均 $5.18 \mathrm{~mm}$, 小児群で 
は平均 $8.08 \mathrm{~mm}$ であった。，小児群は成人群より $\mathrm{Pd} か ゙$ 小さく, Rd が大きな值となっており，表 12 ，図 28 に示 すように Pd/Rd も小さくなっている.この結果は, 側 方運動時非作業側顆頭は小䝨群が成人群より前方に移動 しやすいことを意味している.

さらに，関節窩顆頭間空隙の断面積変化をみてみる と, area $\mathrm{P}$ は成人群で平均 $28.26 \mathrm{~mm}^{2}$, 小坚群では平均 $36.01 \mathrm{~mm}^{2}$ であり, area $\mathrm{R}$ は成人群で平均 $35.02 \mathrm{~mm}^{2}$, 小児群では平均 $32.73 \mathrm{~mm}^{2}$ であった. 小児群は成人群 より area P が大きく, area R が小さな值を示しており， 特に area $\mathrm{P}$ は咬頭嵌合位においては成人群より小さか ったが，運動時には反対に大きな值を示すに至った.こ の結果は，小児群の非作業側顆頭の動きが大きいため顆 頭がその上部を除いて関節窩から前下域一脱出するため に生じたものと思われる.

\section{V. 結 論}

頭部規格断層 X線撮影装置 Sectograph を用いて，正 常咬合を有する平均年齢 23 歳の成人群および平均 年 齢 10 嵅の小児群それぞれ 10 名の左右側を対象として，T. M.J. 付近の形態と咬頭嵌合位における顆頭位および側 方運動時の非作業側顆頭の動きについて検索を行った. それらの結果はつぎのとおりである。

1. 関節窝前方部の形状

1）関節窝最高点から最低点までの関節窩の前後的距 離は成人群で平均 $10.610 \mathrm{~mm}$, 小児群では平均 10.775 $\mathrm{mm}$ であった. また，上下的距離は成人群で平均 7.365 $\mathrm{mm}$, 小児群で柱平均 $6.990 \mathrm{~mm}$ であった. したがって 成人群と小児群との間にはほとんど差は認められない。

2） F-H 平面に対する関節窝前壁中央部を直線 とみ なした基準線との傾斜度は, 成人群で平均 51.8 度, 小 児群では平均 47.3 度であり成人群が小児群より 4.5 度 大きい.

2. 咬頭嵌合位に扔ける顆頭の位置

1）関節窝前壁と顆頭との最接近距離は成人群で平均 $1.96 \mathrm{~mm}$ ，小児群では平均 $1.64 \mathrm{~mm}$ であり，関節窩後 壁と顆頭との最接近距離は成人群で平均 $2.69 \mathrm{~mm}$, 小児 群では平均 $3.01 \mathrm{~mm}$ であった。

2) 関節窝顆頭間空隙の前方域は成人群で平均 25.45 $\mathrm{mm}^{2}$, 小児群では平均 $24.13 \mathrm{~mm}^{2}$ であり, 後方域は成人 群で平均 $25.39 \mathrm{~mm}^{2}$, 小児群では平均 $25.21 \mathrm{~mm}^{2}$ であっ た.

3）顆頭頂の前後的位置は成人群で 平 均 $0.320 \mathrm{~mm}$,
小児群では平均 $0.415 \mathrm{~mm}$ であり, 上下的位置は成人群 で平均 $2.793 \mathrm{~mm}$ ，小児群では平均 $3.038 \mathrm{~mm}$ であった.

3. 側方運動時における非作業側顆頭の動きについて は，小児群が成人群よりも傾斜度は小さいが移動距離は 大きい.

研究の推進にあたってご指導を賜った東京歯科大学 関根 弘 教授および東北菌科大学山口敏雄教授に謝意を表すると同時に ご協力をいただいた本教室元医局長佐野幸史先生および放射線 学教室大坊元二技師に深謝する.

\section{文献}

1）石原寿郎：下䪽運動に関する最近の研究，口腟病会誌， $30: 81 \sim 99,1963$.

2) Zola, A. : Morphologic limiting factors in the temporomandibular joint, J. prosth. Dent., $13: 732 \sim$ 740, 1963.

3) Landa, J.S. : A study of the temporomandibular joint viewed from the standpoint of prosthetic occlusion, J. prosth. Dent., $1: 601 \sim 628,1951$,

4）大石忠雄：下頻運動の立場からみた額関節構造の研究， 補経誌, $11: 197 \sim 220,1967$.

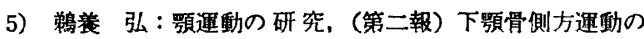
観察，歯科学報，53:577 586, 1953.

6) Posselt, U. : An analyzer for mandibular positions, J. Prosth. Dent., $7: 368 \sim 374,1957$.

7）佐久間博一：Checkbite 法による矢状顆路傾斜角度の測 定に関する研究，第 2 報臨床的実験，菌科学報， $73: 31$ $\sim 58,1973$.

8）中沢 勇：下影運動の補緅学的研究，有歯䫫の運動，口 腔病会誌, $13: 81 \sim 98,1939$.

9）真柳昭紘：側方滑走遇動に関寸る研究，補緅誌， 14 : 158 182, 1970.

10) Isaacson, D. : A clinical study of the condyle path, J. Prosth. Dent., $9: 927 \sim 935,1959$.

11）加藤吉昭：ストロホ撮影法による下额運動，殊に補綴学 的見地から見た運動に関寸る研究，日大医学雑誌，19： 1451 1487, 1960.

12）佐久間孔毅：マルチフラッシュ装置による有歯颚の前後 および開開運動の研究, 口腔病会誌, $26: 1511 \sim 1536$, 1959.

13）河野正司：下顎の矢状面内通動に対応寸る顆頭運動の研 究，第二報マルチフラッシュ装置による矢状面運動軸の 解析, 補経誌, $12: 350 \sim 380,1968$.

14）河野正司：下顎の矢状面内運動に対応する顆頭運動の研 究，第一報断層X線規格写真仁上る観察，補緅誌，12： 
$166-818$

337 349, 1968

15) Ricketts, R.M. : Variations of the temporomandibular joint as revealed by cephalometric laminagraphy, Amer. J. Orth. $36: 877 \sim 898,1950$.

16) Williamson, E.H. : Laminagraphic study of mandibular condyle position when recording centric relation, J. prosth. Dent., $39: 561 \sim 564,1978$.

17) Sheppard, I.M. : The effect of hinge axis clutches on condyle position, J. prosth. Dent., $8: 260 \sim 263$, 1958.

18）大森明彦： $X$ 線テレビ映画法による下影頭の運動変化に ついて，歯科学報，79:99 114，1979.

19）根本一男：有歯瀕の下說切歯点における 3 次元的運動限 界の研究, 補緅誌, $6: 1 \sim 40,1962$.

20）藍 秢: 切歯点部における咀嚼運動の解析, 補緅誌, $6: 164 \sim 200,1962$.

21) Alan High : Condyle Position in the Untreated Orthodontic Patient, Proceedings of th Foundation
27 巻 4 号 (1983)

for Orthodontic Research : 39 42, 1978.

22）早坂正博, 高橋健二, 片岡保失, 田島篤治：Sectogra$\mathrm{ph}$ による顆頭位の研究, 第 1 報 各下頻位における顆頭 位について, 補緅誌, $27: 550 \sim 572,1983$.

23）早坂正博, 高橋健二, 酒井靖彦, 浅野健, 田中義博, 近江谷尚紀, 片岡保失, 田島篤治: Sectograph に上る 顆頭位の研究，第 2 報咬合力発現時における顆頭の移動 について，補緶誌，27:573 584, 1983.

24）森永登規雄：日本人頻関節の研究，第 4 篇所謂少年, 青 年期に於ける䝷関節の所見, 口腔病会誌, $16: 1 \sim 20$, 1942.

25）森永登規雄: 日本人䫑関節の研究, 第 6 篇全篇の総括的 観察, 口腔病会誌, $16: 39 \sim 45,1942$.

26）小池将浩：下影窝の発育に関する研究，歯科学報，70： 1409 1428, 1970.

27）黑田百樹：下䫑頭の下頡裔に対する位㯰に関する研究, 歯科学報, $74: 368 \sim 418,1974$. 